\title{
Analysis on Effect of Cold Stress in Bean Seeds (Phaseolusvulgaris I)
}

\author{
Vandana Srivastava, Anish Soni, Kumari Sonam \\ Science in Biotechnology, $4^{\text {th }}$ SEM (Biotechnology), PES COLLEGE Affiliated to Bangalore University, Bangalore, India
}

\section{Email address:}

vandana.srivaastava@gmail.com (V. Srivastava), anish.soni.kiran@gmail.com (A. Soni), singhsonam865@gmail.com (K. Sonam)

\section{To cite this article:}

Vandana Srivastava, Anish Soni, Kumari Sonam. Analysis on Effect of Cold Stress in Bean Seeds (Phaseolusvulgaris l). American Journal of BioScience. Vol. 3, No. 4, 2015, pp. 145-166. doi: 10.11648/j.ajbio.20150304.15

\begin{abstract}
Low temperature or cold stress is one of the major abiotic stresses for bean seeds production. The objective of this study was to analyze the effect of cold stress on Phaseolusvulgaris $l$ seeds by doing different types of tests(germination studies, respiration response, conductivity test, amylase and catalase test) at different temperatures like room temperature, at $3^{\circ} \mathrm{C}$ and at $-19^{\circ} \mathrm{C}$. Seeds were germinated in germination box. Germination percentage, rate, seed vigour and germination index was measured. Respiration response was also analyzed. The procedure does not quantify a respiration rate, but it indicates that respiration rate can be compared across different treatments. Observation from conductivity measurement shows that leachate solution of $-19^{\circ} \mathrm{C}$ gives low conductivity whereas $3^{\circ} \mathrm{C}$ gives moderate and at normal room temperature it was high. Low temperature showed high amylase as well as catalase activity. Room temperature showed a good response against few parameters but not in enzyme activity.
\end{abstract}

Keywords: Effects, Cold Stress, Temperature, Bean Seeds (Phaseolus Vulgaris $l$ )

\section{Introduction}

Phaseolus vulgaris, the green bean, kidney bean, or common bean, is an herbaceous annual plant in the Fabaceae (legume or bean family) that originated in Central and South America and is now cultivated in many parts of the world for its beans, which can be harvested and eaten immature, still in the edible pod, or when mature, shelled, and dried. Numerous cultivars of green beans have been developed, including string beans, stringless varieties (such as the slender French haricot varieties), and snap beans. Cultivars of dried (or shelling) beans from this species are even more diverse, among them the following: black beans (or black turtle beans); cranberry beans (tan speckled with maroon, or white speckled with crimson); kidney beans (which may be light or dark red, and come in various sizes); cannellini or white kidney beans; pinto beans (the speckled varieties used in many Latin American dishes); and various white beans (also called navy beans).

P. vulgaris varieties have been developed to have both bush and twining forms. The bush forms, which grow in erect leafy clumps, reach $1 \mathrm{~m}(3.25 \mathrm{ft})$ tall, while twining forms, which need to be supported with poles or trellising, grow up

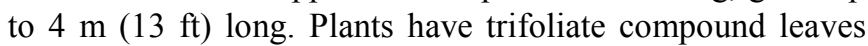

with oval to rhombic leaflets, each up to $16 \mathrm{~cm}$ (9.25 in) long, which are pubescent (covered with downy hair). The flowers, which may be white, yellow, violet, or red, in loose, open unbranched clusters (racemes) that are shorter than the leaves, and develop into linear Round to slightly flattened pods upto $15 \mathrm{~cm}$ (6.75 in) long.

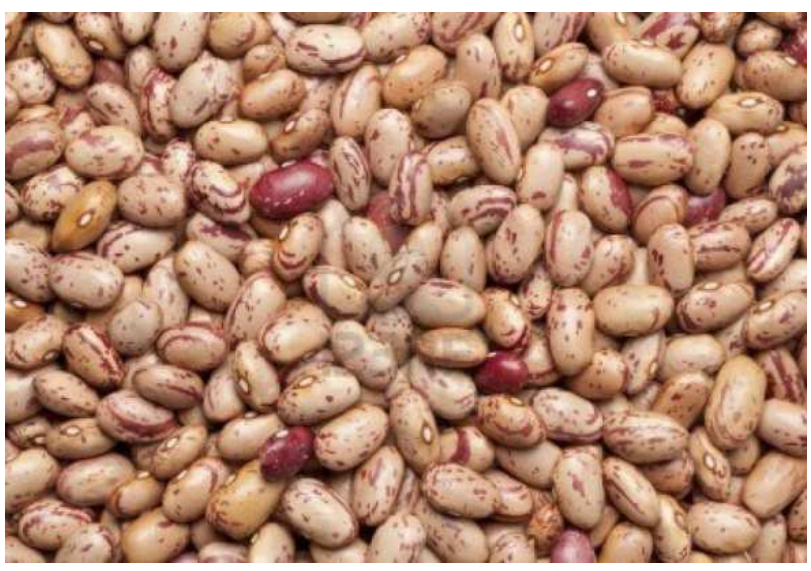

Figure 1. Phaseolus vulgaris l. 
Classification: Phaseolusvulgaris $L$.

\begin{tabular}{ll}
\hline Kingdom & Plantae - Plants \\
\hline Subkingdom & Tracheobionta - Vascular plants \\
Superdivision & Spermatophyta - Seed plants \\
Division & Magnoliophyta - Flowering plants \\
Class & Magnoliopsida - Dicotyledons \\
Subclass & Rosidae \\
Order & Fabales \\
Family & Fabaceae - Pea family \\
Genus & Phaseolus L. - bean \\
Species & Phaseolusvulgaris L. - kidney bean \\
\hline
\end{tabular}

The U.N. Food and Agricultural Organization estimates that total commercial production of dried beans (which includes numerous varieties of $P$. vulgaris but also includes some beans of other species, including P. lunatus, but does not include green beans) was 23.23 million metric tons worldwide in 2010, harvested from 29.92 million hectares. India was the leading producer, responsible for $21 \%$ of total production, followed by Brazil, Myanmar, China, the U.S., and Mexico. Within the U.S., the major dried-bean producing states in 2007 were North Dakota, Michigan, Nebraska, Minnesota, and Idaho (Bailey et al., 1976).

The leaf is occasionally used as a leaf vegetable, and the straw is used for fodder. Botanically, with other species of the bean genus (Phaseolus), it is classified into legumes family (Fabaceae), so they acquire their nitrogen through an association with rhizobia: species of nitrogen-fixing bacteria (Phillips, R. and Rix, M., 1993).

Abiotic stress is stress produced by natural factors such as temperature, cold, heat and salinity. One of the types of abiotic stress is cold. This has a huge impact on farmers. Cold impacts crop growers all over the world in every single country. ROS stands for reactive oxygen species. ROS plays a large role in mediating events through transduction. Cold stress was shown to enhance the transcript, protein, and activity of different ROS-scavenging enzymes. Low temperature stress has also been shown to increase the $\mathrm{H}_{2} \mathrm{O}_{2}$ accumulation in cells. Plants seeds can be acclimated to low or even freezing temperatures. If a plant seeds can go through a mild cold spell this activates the cold-responsive genes in the plant. Then if the temperature drops again, the genes will have conditioned the plant to cope with the low temperature. Even below freezing temperatures can be survived if the proper genes are activated (Suzuki and Mittler, 2006).

Cold shock response is the physiological response of organisms to sudden cold, especially cold water. Living organisms encounter various stresses, change in temperature being one of the most common. Fluctuations in temperature have widespread effects on the growth and survival of plant, which have therefore developed mechanisms that allow them to adapt to these changes. The cold-shock response is one such mechanism; it consists of a number of adaptive changes ranging from alterations in membrane composition to alterations in the global protein profile of the cell (Thomashow M.F., 1998).

\subsection{Study Comprised of Following Objectives}

- Effect of cold stress on germination activity,

- Effect of cold stress on respiration activity,

- Conductivity measurement of seeds exposed to cold stress,

- Amylase and catalase activity in seeds exposed to cold stress.

\subsection{Review of Literature}

\subsubsection{Cold Response in Seed Germination}

Cold response is a highly complex process that involves physiological and biochemical modifications. Furthermore, alterations of the expression patterns of many genes, proteins and metabolites in response to cold stress have been reported. Plants require specialized mechanisms to survive exposure to low temperature. Cold stress can be classified as chilling $(0$ $\left.15^{\circ} \mathrm{C}\right)$ and freezing $\left(<0{ }^{\circ} \mathrm{C}\right)$ stresses. . Multiple primary sensors are thought to be involved in stress sensing. Each sensor may perceive a specific aspect of the stress and may be involved in a distinct branch of the cold signaling pathway. Plants may sense low temperature through changes in the physical properties of membranes, because membrane fluidity is reduced during cold stress. In fact, plasma membrane rigidification raised by a membrane rigidifier, dimethyl sulfoxide (DMSO), can induce the expression of COR (cold-responsive) genes, even at normal growth temperatures, whereas the application of a membrane fluidizer, benzyl alcohol, prevents the induction of COR gene expression at low temperatures (Kenji Miura and Tsuyoshi Furumoto, 2013).

Plants on exposure to low temperature acquire freezing tolerance. Freezing injury in most plants and tissues occur by from severe cellular dehydration that occurs upon ice formation and cellular membrane systems are a primary site of freeze-induced injury. Cold responsive genes get activated in response to low temperature (Michael F. Thomashow, 2001).

Studies on seed germination on different physiological parameters like (germination rate, germination percentage, seedvigour and germination index) are important to solve taxonomic and phylogenetic problems, to contribute to the knowledge of plant morphology through the ontogenesis, to recognize species in the field. Moreover, these studies reinforce the necessity of conservation of some species in forest and tropical regions also (Andreataand Pereira, 1990).

Temperature and relative humidity together cause rapid decline in seed quality during storage. The pattern of seed longevity and storage potential of different species have been studied by several workers both for long and medium term under ambient and controlled storage conditions and for short term under accelerated ageing conditions. The accelerating ageing test, in which seed is incubated for a short period (a few days) under low temperature conditions, was first developed by Delouche and Baskin (1973) for predicting the storability of seed.

Cold tolerance during seed germination was defined as the 
inverse of the ratio of germination time under cold stress to germination time under control conditions and referred to as germination tolerance index (Foolad, M.R andLin, G.Y.2000)

Plants on exposure to low temperature acquire freezing tolerance. Freezing injury in most plants and tissues occur from severe cellular dehydration that occurs upon ice formation and cellular membrane systems are a primary site of freeze-induced injury. Cold responsive genes get activated in response to low temperature (Su Jung Park et al. 2013).

Seed germination and vigour are the main physiological quality attributes. Vigour testing- is important because it often gives a better prediction of field performance and is a more sensitive indicator of seed quality than the standard germination test (Makkawil et.al., 1999).

Seeds germinate in a wide range of environmental conditions, yet the major determinant of germination is the availability of water. Under unfavorable conditions germination is delayed or entirely suppressed depending on the stress intensity and the genetic background. Annual plants inhabiting semi-arid to arid regions have developed unique strategies including a tight regulation of germination ensuring species survival in spite of an unpredictable regime of precipitation (Bing Bai et.al, 2011).

Water stress affects practically every aspect of plant growth and metabolism. Plant responses to water deficit depend upon various factors such as duration and degree of stress, growth stage and time of stress exposure. Due to their sedentary mode of life, plants resort to many adaptive strategies in response to different abiotic stresses such as high salt, dehydration, cold and heat, which ultimately affect the plant growth and productivity (Arun Dev Sharmaetal., 2000).

Seedling is the most vulnerable stage in life cycle of plants and germination determines when and where seedling growth begins. The emergence of radical/plumule or root/shoot from seeds is usually taken as an index of germination (\%).

The duration of cold stratification has positively effective on germination percentage and rate of the seeds. When the duration of cold stratification increases, the germination percentage of the seeds was increased, but the average rate of germination was decreased (Zafer Olmez, Askin Gokturk, 2006).

Growth tests are based on the principle that vigorous seeds grow at a faster rate than poor vigour seeds even under favorable environments. Vigorous seeds rapidly germinate, metabolize and establish in the field. So, any method used to determine the rapidity of growth of the seedling will give an indication of seed vigour level (Gupta P.C, 1984).

Seed vigour is an important quality parameter which needs to be assessed for a seed lot in the field or in storage. Seedvigour is " the sum total of those properties of the seed which determine the level of activity and performance of the seed or seed lot during germination and seedling emergence"'. Seed vigour is described as performance of seeds when sown in the field .Seed vigour is affected by several factors like genetic constitution, environment and nutrition of mother plant. Maturity at harvest, seed weight and size, mechanical integrity, deterioration and ageing and pathogens are known to influence seed vigour.

Germination percentage and rate were determined according to stratification time applied. Below formula was used when determining germination rate (Pieper, 1952):

$$
\mathrm{GR}=(\mathrm{n} 1 * \mathrm{t} 1)+(\mathrm{n} 2 * \mathrm{t} 2)+(\mathrm{n} 3 * \mathrm{t} 3) \ldots \ldots .(\mathrm{ni} * \mathrm{ti}) / \mathrm{T}
$$

GR: Germination rate, n: Number of days for each counting of germinated seeds. t: number of germinated seeds in each counting day. T: Total number of germinated seeds (Gupta P.C, 1984).

Abiotic stresses adversely affect growth, productivity and trigger a series of morphological, physiological, biochemical and molecular changes in plants. Cold stress is a major environmental factor that limits the agricultural productivity of plants in hilly areas. Plants respond and adapt to this stress to survive under stress conditions at the molecular and cellular levels as well as at the physiological and biochemical levels. However, expression of a variety of genes is induced by different stresses in diverse plants (Gulzar S. et al., 2011).

Low temperature often affects plant growth and crop productivity, which causes significant crop losses. Plants differ in their tolerance to chilling $\left(0-15^{\circ} \mathrm{C}\right)$ and freezing $(<$ $0^{\circ} \mathrm{C}$ ) temperatures. In general, plants from temperate climatic regions are considered to be chilling tolerant with variable degree, and can increase their freezing tolerance by being exposed to chilling, non-freezing temperatures, a process known as cold acclimation, which is associated with biochemical and physiological changes and ultimately showed marked changes in gene expression, biomembrane lipid composition, and small molecule accumulation (Gulzar S et.al., 2011).

Low temperature affects the growth and productivity of plant. Seedling adapt to stress environment by different mechanism, including changes in morphological developmental pattern as well as physiological and biochemical process (Hong-Xing Cao, Cheng-Xu Sun, 2011).

The physical state of water in seeds during storage and its changes during imbibition strongly influence the germination under varying environmental condition. The binding nature of seeds water influences its quality, germination and emergence. Water is an important substrate in many reactions and its effect on phospholipid structure plays an important role in membrane stability (Nabamita Chatterjee and Shantha Nagarajan, 2006).

Seed germination is controlled by several environmental factors like moisture, temperature and water content. Seed quality is a major factor which control its germination like seed coat may be water impermeable or mature seed may contain an underdeveloped embryo that grow to its full size after imbibition. Seed stored in dry condition show lower germination and slower emergence than in the wet condition. Moisture condition is necessary for seed germination (Takahiro Tezuka, Hisa Yokoyama, 2012).

exploring new schemes for catalasepurification (Sinha, A.K ,1972). 


\subsubsection{Respiration Response}

Plants need energy to metabolize their stored sugars through cellular respiration. Plants need energy to maintain homeostasis, to perform certain functions like transporting sugars, and to grow. A plant's respiration rate is not consistent and depends on many factors. After a seed drops from a plant it usually goes into a resting period called dormancy when it metabolizes stored energy reserves very slowly (Lynn Vaccaro, 2003). Dormancy is defined as a state during which the seed is not able to germinate. To fulfill the high-energy needs of a germinating seedling, cellular respiration increases as a seed emerges from dormancy and begins germinating. However, seeds respire at a lower rate throughout dormancy. In fact, seed suppliers measure seed respiration using a highly sensitive method to determine if dormant seeds are still viable and suitable for cultivation. The timing of seed germination will strongly influence the success of a seedling. If a seed emerges too early in the spring it could die of frost. Wild flowers native to deciduous forests often take advantage of the high light period before trees put out new leaves or after trees lose their leaves; if these seeds wait too long to germinate they could miss their window of opportunity. As a result, seeds have evolved complex ways of detecting that window of opportunity. For example, many seeds can detect the quality or spectral composition of light. Sunlight that passes through a canopy of leaves is depleted in red light relative to the amount of far red light (longer wavelength). Thus, the proportion of light of different colors will trigger germination of wildflower seeds, allowing these seeds to avoid being shaded by trees (Bewley, J.D., and M. Black, 1985).

Some seeds have to wait for years before they are able to germinate. During this time, seeds cannot make their own food because they lack leaves! Therefore, in order for a seed to stay alive or to grow it needs to use stored energy reserves and undergo cellular respiration. The seed will use those calories to survive during dormancy and to germinate.

When plants use sugars stored in their leaves or seeds they undergo cellular respiration

Sugar + Oxygen à Carbon dioxide + Water + Energy (ATP)

As the seeds respire they take in oxygen and release carbon dioxide at roughly the same rate. If left alone in a sealed test tube, the carbon dioxide would replace any oxygen utilized by the seeds and the air pressure would remain relatively constant. In this experiment, any carbon dioxide released in the test tube reacts with the calcium hydroxide to form solid calcium carbonate, also known as calcite or limestone. This process essentially removes all gaseous carbon dioxide from the air space in the test tube and converts it to a solid. As more carbon dioxide is produced, more carbon dioxide is removed from the air and the air pressure in the test tube declines, essentially sucking water up into the test tube. If atmospheric pressure is higher outside the test tube than inside the test tube, water will rise in the test tube. Theoretically, the difference in air pressure should equal the weight of the water that rose in the test tube. Thus, the height of the water in the test tube is an indicator of the amount of respiration that occurred (Lynn Vaccaro, 2003). Amount of oxygen used by plants can be measured with a device called respirometer (Bewley, J.D., and M. Black, 1985).

During germination, seeds use sugars and other molecules as a substrate for respiration. Germination of a seed begins with water uptake by the seed. This process is called imbibition. The uptake of water by a seed is an essential step in order for the seed to germinate. The total amount of water taken up is about 2-3 times the weight of the seed. The extent to which germination has progressed can be determined by measuring water uptake or respiration (Bewley, J.D., and M. Black, 1985).

Most seeds dry out and are in a dormant condition before germination. In this state, their metabolism is extremely slow. When sufficient moisture is present in the environment, seeds absorb water and swell. This triggers enzyme activity. All seeds store nutrients, usually starch, and the appropriate enzymes digest it to release glucose as an energy source. With a supply of energy, cellular respiration can occur.

\subsubsection{Conductivity Test}

Seed gene banks often have limited quantities of seed available for testing; therefore, it is important to develop a method to test a seed sample without destroying it. Determining seed viability traditionally has involved a standardized germination test, which is obviously destructive to seed and labor intensive. Electro conductivity (EC) measurements of single seed leachate solutions could lead to the replacement of the standard germination test if the measurements could be taken early during imbibition, which, in turn, would lead to the development of nondestructive testing methods for seed quality i.e., viability and vigor determination (Matthews and Bradnock, 1968).

Electrolytes are substances that produce free ions when they are dissolved in a suitable solvent like water. The dissociation process take place when electric current is passed molecules are split in to atomic components called ions. Positively charged ions are called cations and negatively are called anions. Due to the presence of free ions, electrolyte solutions behave as an electrically conductive medium (Sarka K., Kopecky, F, 1990).

A simple procedure based on the electrical conductivity of seed leachates has recently been developed for the southern pines. This test is based on the principle that seeds leach numerous substances when soaked in water and that because of membrane deterioration the amounts leached will increase as the seeds deteriorate. Although several chemical constituents can also be determined, the electrical conductivity of the leachate can be measured more quickly and easily (Bonner,F.T., 1991).

The electrical conductivity is based on the principle that the deterioration process is the leaching of the cells of seeds soaked in water due to loss of integrity of cellular systems. Thus, low conductivity means a high-quality seed and high conductivity suggest low quality seeds.The effect of 
temperature on conductivity readings depends on the solution being measured. The effect is greatest in low ionic strength (low conductivity) solutions. A general rule to follow is there will be a $2 \%$ changes (increase)/degree C. (Davidson, K.G.V, Moore, F.G. 1994).

When seeds are immersed in water for conductivity test and kept in freeze for $24 \mathrm{hrs}$ the weaking of cell membrane takes place which causes leakage of water soluble compounds like amino acids, electrolytes and sugar. Whereas fresh seeds have intact membrane so they leach fewer amounts of these chemicals. The measurement of electrical conductivity is measured by conductometer which gives the estimation of membrane permeability (Gupta P.C.1984). Conductivity can be used for estimation of seed quality and viability of seeds (Bonner, F.T., 1991). This test helps to know the physiological quality of seeds (Kennya Mara et al., 2012). The electrical conductivity is based on the amount of seed deterioration is proportional to the cell membrane integrity. Leachate electro conductivity test was proposed as a seed quality test which is rapid and simple (Davidson, K.G.V, Moore, F.G. 1994).

\subsubsection{Enzymes and Stress}

Several stresses in plants alters metabolic processes which lead to production of reactive oxygen species which is protected by antioxidant defense system present in plants and enzymes like catalases, amylase and peroxidases (Amjad Hameed, Shazia Naseer et al.,2008).Reactive oxygen species (ROS) play a significant role in plant growth, development, and interaction with biotic and abiotic environments .ROS have also been implicated as important regulatory and signaling elements in a variety of cellular processes . ROS are constantly produced during the course of photosynthesis and respiration, whereas redox homeostasis in the cell is tightly controlled by redundant protective mechanisms (Vladimir Shulaev, David Oliver, 2002).

Chilling condition leads to the formation of reactive oxygen species which cause oxidative damage to plants. This is protected by enzymes like catalase, peroxidase which eliminate ROS and keep a homoeostasis between production and cleaning of ROS and thus reduces the formation of free radicles (Ya-jing Guan, Jin $\mathrm{Hu}, 2009$ ).

\subsubsection{Amylase}

Amylases hydrolyze starch and glycogen into sugars. There are 2 types of amylases: $\alpha$ amylase $\& \beta$ amylase. $\alpha$ amylase is an endohydrolase which hydrolyses the $\alpha-1 \rightarrow 4$ linkage within the chain and breaks these polymers into small fragments. In contrast $\beta$ amylase is an exohydrolase and it starts acting from non-reducing end removing two glucose molecules at a time. The products thus formed are a disaccharide, $\beta$-maltose, and limit dextrin. The hydrolytic action of $\beta$-amylase results in increasing reducing power of the starch solution due to release of a large number of molecules of the reducing sugar viz.maltose. The reducing sugars can be determined quantitatively by their reaction with dinitrosalicylic acid with absorption maxima at $570 \mathrm{~nm}$. Plants have developed a series of enzymatic and non- enzymatic detoxification systems to counteract ROS, and protect cells from oxidative damage. The antioxidant enzymes such as SOD, CAT, POX, and GR function in detoxification of super oxide and $\mathrm{H}_{2} \mathrm{O}_{2}$. $\beta$-amylaseexpressed during stress has been shown to play a major role in transitory breakdown of starch (Sawney, S.K, Randhir Singh,1996).

Beta-amylase is a exoamylase that hydrolyzes $\alpha$ 1,4 glycosidic linkages of polyglucan chains at the non reducing end to produce maltose. $\beta$ - amylase is involved in starch breakdown in plants (Fatma Kaplan and Charles L. Guy, 2004).

Beta-amylase and alpha-amylase are involved in degradation of endosperm starch. Starch present is hydrolysed in to glucose by a action of a and beta-amylases, debranching enzyme and a-glucosidases (maltase) (Tuomas Sopanen and Christiane Lauriere, 1988).

Amylase activity is essential for providing energy and carbon to growing embryo through respiratory breakdown of utilizable substrates. The onset of germination or from quiescent stage to active phase is supported by stored ATP and breakdown of stored lipid. The providing of utilizable substrate is mainly done by amylase until the seed become photosyntheticallyself sufficient (Soman Nandi and Gitali Das, 1994).

Amylases are starch degrading enzymes. The reducing sugar produced by amylases react with dinitrosalicyclic acid and reduce it in to a brown coloured product called nitro aminosalicyclic acid. The nitro aminosalicyclic acid will show the rate of maltose released by starch. Beta-amylase hydrolyses alternate bonds from the non-reducing end of the substrate. The enzyme degrades amylose, amylopectin or glycogen in an exo-or stepwise fashion by hydrolysing alternate glycosidic bonds. The end product is beta-maltose (Peter Bernfield, 1955)

Germinating seeds show high amylase activity as amylase mobilize stored food (starch and protein) for the survival of young plant until it is capable of making its food by photosynthesis(Afiukwa, C. A, Ibiam, U. A, 2009).

\subsubsection{Catalase}

Catalase is present in the peroxisomes of nearly all aerobic cells and serves to protect the cell from the toxic effects of hydrogen peroxide by catalyzing the decomposition of $\mathrm{H}_{2} \mathrm{O}_{2}$. The mechanism of catalysis is not fully elucidated, but the overall reaction is as follows: $2 \mathrm{H}_{2} \mathrm{O}_{2} \longrightarrow 2 \mathrm{H}_{2} \mathrm{O}+\mathrm{O}_{2}$

Catalase is an antioxidant enzyme ubiquitously present in mammalian and non-mammalian aerobic cellscontaining a cytochrome system. It was initially isolated from ox liver and later from blood, bacterial, and plant sources. The enzyme contains 4 ferrihemoprotein groups per molecule. The enzyme has a molecular mass of $240 \mathrm{kDa}$. In eukaryotic cells the enzyme is concentrated in the subcellular organelles called peroxisomes (microbodies). Catalase catalyses the decomposition of hydrogen peroxide $\left(\mathrm{H}_{2} \mathrm{O}_{2}\right)$ to water and oxygen. Hydrogen peroxide is formed in the eukaryotic cell as a by-product of various oxidase and superoxide dismutase 
reactions. Hydrogen peroxide is highly deleterious to the cell and its accumulation causes oxidation of cellular targets such as DNA, proteins, and lipids leading to mutagenesis and cell death.5-8 Removal of the $\mathrm{H}_{2} \mathrm{O}_{2}$ from the cell by catalase provides protection against oxidative damage to the cell. It's role in oxidative stress related diseases has been widely studied (Deisseroth, A., and Dounce, A.L.,1970).

Enzymes are proteins that catalyze specific reactions in living organisms.In many cases, enzymes can be purified and studied in vitro. Spectrophotometric enzyme assays can be conducted qualitatively: that is, simply showing the general procedure, the formation of a colored product, the process of measuring absorbance, and so forth. On the other hand, a quantitative approach would focus on careful measurements. It can be take it to the level of exploring new schemes for catalasepurification (Sinha, A.K ,1972).

\section{Materials and Methods}

\subsection{Cold Stress on Germination}

\subsubsection{Plant Material}

Seeds of bean plant (Phaseolus vulgarisl) were taken for germination studies. Seeds were collected from Horticulture Department of Lalbagh, Bangalore. From the seed lots, seeds having uniform size, colour and shape with intact seed coats were selected by hand picking. The seeds were surface sterilized in bavistin solution for ten minutes, and rinsed several times with distilled water. These surface sterilized seeds were taken for germination in germination box. 30 seeds were counted and sowed in moistened towel in a germination box. These germination boxes were well ventilated for aeration. This type of three set up were made for different temperature treatment.

\subsubsection{Temperature Treatment}

This experiment was conducted in a completely randomized design with 3 different temperatures. Experiment is conducted in a germination box $(19 \mathrm{~cm}$ length $* 12.5 \mathrm{~cm}$ breadth* $6.7 \mathrm{~cm}$ height). Three germination boxes were taken for germination studies for cold treatment of seeds. Moistened paper towel was kept in the germination box and surface sterilized seeds were sowed in the germination box with cover. This type of temperature treatments were given to bean seed lots at normal room temperature, $3^{\circ} \mathrm{C}$ and $-19^{\circ} \mathrm{C}$ for 15 days. The treated seeds in each germination boxes were subjected to germination studies. These seeds were constantly moistened by spraying with water.

\subsubsection{Germination Studies}

These germination boxes were observed for 15 days. After one day interval seed germination were recorded. Each day shoot length was measured and no. of germinated seeds were also recorded. By observation germination percentage, germination rate, germination index and seed vigour index were calculated of each treated temperature.

Germination percentage $=$ (no of seeds germinated $/$ total no of seeds taken for germination) $* 100$
Germination $\quad$ rate $=(\mathrm{n} 1 * \mathrm{t} 1)+(\mathrm{n} 2 * \mathrm{t} 2)+(\mathrm{n} 3 * \mathrm{t} 3) \ldots \ldots . .(\mathrm{ni} * \mathrm{ti}) / \mathrm{T}$ (Pieper, 1952)

$\mathrm{n}$ : Number of days for each counting of germinated seeds. t: number of germinated seeds in each counting day. T: Total number of germinated seeds.

Seedling vigour was calculated following Abdul Baki and Anderson (1973) -

Vigour index $=($ Germination $\% *$ Seedling length $)$

Germination index (GI) was calculated according to Copeland and McDonald (1995) using the formulae-

Germination index $=$ (no of germinated seeds/ days of first count) + --------+ (no of germinated seeds / days of final count)

\subsection{Respiration}

\subsubsection{Seed Source}

The collected seeds were stored in polyethylene jars at room temperature for subsequent studies.

\subsubsection{Experiment}

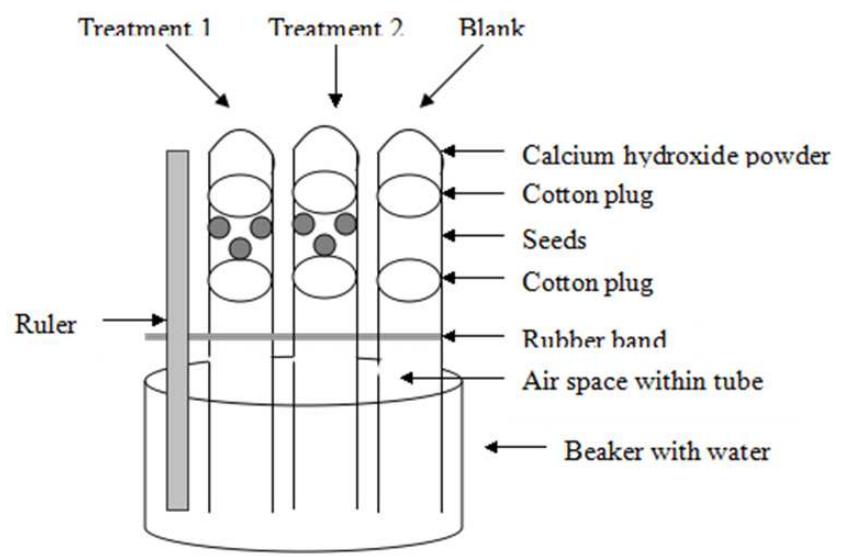

Figure 2. Diagram of the protocol for measuring respiration.

In this experiment, Seeds were soaked in water for half an hour. These seeds were taken for the experiment. A substance called Calcium hydroxide powder (SDFCL, S D Fine Chem. Limited) also called hydrated lime was used to absorb $\mathrm{CO}_{2}$ in this experiment. The calcium in either substance will react with and absorb any carbon dioxide produced by the seeds during respiration. Calcium hydroxide is a strong base and will cause irritation and burns upon contact with skin. Gloves and eye protection should be worn and contact with skin and clothing should be avoided. Seeds were kept inmedium sized test tubes that contain calcium hydroxide, and then the tubes were inverted in a beaker (usually borosilicate glass) of water. The calcium hydroxide will react with any carbon dioxide that is produced and remove the gas from the test tube air space. As the seeds respire, they are taking in oxygen and respiring out carbon dioxide, but the carbon dioxide is absorbed by the calcium hydroxide. As a result, the amount of air in the sealed test tube actually decreased and water raised in the test tube. In a closed vessel containing seeds which are respiring, the concentration of oxygen will 
decrease and concentration of carbon dioxide will increase but because of chemical calcium hydroxide powder inside the beaker, the pressure in the beaker decreases as oxygen is absorbed by the seeds (Roberts, M.B.V.1987) This provides a visible indication that respiration is actually occurring. The set up is like in this manner:-

Like wise there is one more set is done as Control in which test tube contain all the contents as same in previous but there is no seed in it. The decrease in level of water in each beaker at different exposed temperature(normal room temperature, $3^{\circ} \mathrm{C}$ and $-19^{\circ} \mathrm{C}$ was measured everyday till one week( refer table no 5 and graph no 6 ).

\subsubsection{The Reaction}

As the seeds respire they take in oxygen and release carbon dioxide at roughly the same rate. If left alone in a sealed test tube, the carbon dioxide would replace any oxygen utilized by the seeds and the air pressure would remain relatively constant. In this experiment, any carbon dioxide released in the test tube reacts with the calcium hydroxide to form solid calcium carbonate, also known as calcite or limestone. This process essentially removes all gaseous carbon dioxide from the air space in the test tube and converts it to a solid. As more carbon dioxide is produced, more carbon dioxide is removed from the air and the air pressure in the test tube declines, essentially sucking water up into the test tube. If atmospheric pressure is higher outside the test tube than inside the test tube, water will rise in the test tube. Theoretically, the difference in air pressure should equal the weight of the water that rise in the test tube $\left(\mathrm{P}_{1}-\mathrm{P}_{2}=\right.$ weight of water). Thus, the height of the water in the test tube is an indicator of the amount of respiration that occurred. It is theoretically possible to calculate a respiration rate from the change in the volume of air in the test tube, but changes in humidity and barometric pressure could complicate the calculations (Lynn Vaccaro,2003).

\subsection{Conductivity}

\subsubsection{Seed Collection}

The collected seeds were stored in polyethylene jars at room temperature for subsequent studies.

\subsubsection{Conductivity Test}

The development of tests to evaluate the physiological quality of seeds, as well as the standardization of these is essential for the establishment of an efficient quality control. The measurement of electrical conductivity through the electrolyte amount released by soaking seeds in water has been applied by the individual method where each seed is a sample or more often, a sample of seed representative of a population (mass method). For this case, the results represent the average conductivity of a group of seeds, may a small amount of dead seeds affect the conductivity of a batch with many high-quality seed generating a read underestimated.

To minimize this problem, seeds were chosen, excluding the damaged seeds. 25 seeds were tested for each temperature treatment. Seeds were placed into containers holding $5 \mathrm{ml}$ of distilled water and left to soak for 24 hours. After 24 hours leachate solution was used to check the conductivity of seed sample.

\subsubsection{Conductivity Procedure}

Conductometer was plugged on. $50 \mathrm{ml}$ beaker was filled with a solution of KCl- $0.1 \mathrm{~N} \mathrm{KCl} \mathrm{(MERCK)} \mathrm{standard}$ solution: $0.74 \mathrm{gm}$ of $\mathrm{KCl}$ powder was mixed in $100 \mathrm{ml}$ of distilled water. Conductometric container was dipped into the beaker such that all three platinum fillets are immersed in the solution. The 'scale selector' knob be brought to 200 millimhos position (maximum). The 'Read/Cal' knob be brought to 'Cal', \& The 'Cal' be operated to display 100 in the display panel.Now, The cell be dipped in $\mathrm{N} / 10 \mathrm{KCl}$ (specific conductivity of $\mathrm{N} / 10 \mathrm{KCl}$ at present temperature) The 'scale selector' knob be brought to 20 millimhos position $\&$ 'Read-Cal' knob be brought to 0.95 position. After that the 'scale selector' knob be brought to 'Read' position. The meter is supposed to display a value which is little less than 14.12.The 'cell constant' knob be adjusted, so that, the meter reads according to present temperature. Value of conductance was read andconductometric container was taken off the solution. $\mathrm{KCl}$ solution was poured back to the storage bottle. Conductometric container was carefully rinsed and dried. The 'Read/Cal' knob be brought to 'cal' position. Then cell be rinsed with distilled water.

Conductance of distilled water was measured to ensure that the beaker and conductometric container are clean. The conductance has to be less then $10 \mathrm{~S}$ and it was found to be $0.5 \mu \mathrm{S}$. Next the cell was dipped in sample water. The Read /Cal knob be brought to Read position and The scale selector knob be rotated anticlockwise from 200 millimhos position(highest value)gradually stage by stage to the 20 micromhos mark(lowest value), till the meter displays 1.0. Now, the 'scale selector'knob be rotated clockwise stage by stage and to be stopped at that point where we get the highest value. Conductivity of the leachate solution (unknown solution) of seeds which kept at different temperatures after soaking of 24 hours as well as leachate solution of germinating seeds of 6 days was measured ( table no 6 ,7and graph no 7).

\subsection{Amylase}

\subsubsection{Plant Material and Other Materials Used}

Seeds were surface sterilized and kept for germination at different temperature of $-19{ }^{\circ} \mathrm{C}, 3{ }^{\circ} \mathrm{C}$ and at room temperature for period of 2 to 3 days. Then on $8^{\text {th }}$ day seeds cover was removed and they were weighed on weighing balance separately. They were used for estimating amylase activity. Boiling water bath, centrifuge, test tubes, measuring cylinder, pipette, test tube stand, colorimeter etc were needed for performing experimental procedure.

\subsubsection{Preparation of Reagents}

Different reagents were prepared for standard maltose curve and amylase extraction and assay. Dinitrosalicylic acid (SDFCL) was prepared by dissolving 1 gram of DNS, $200 \mathrm{mg}$ 
crystalline phenol and 50mg sodium sulphite in $100 \mathrm{ml} 0 \mathrm{f} 1 \%$ $\mathrm{NaOH}$ was kept in reagent bottle. Sodium potassium tartarate (MERCK $40 \%$ ) was prepared by taking 40 gram of sodium potassium tartarate and dissolving it in small amount of water and making the final volume upto $100 \mathrm{ml}$ with water and was kept aside in a reagent bottle. The starch solution (SDFCL$1 \%$ ) was prepared as follows: $1 \mathrm{gm}$ of starch was weighed and $100 \mathrm{ml}$ of boiling water was added to it.It was boiled for 2-3 minutes then it was cooled and filtered. Filtrate was used as a substrate solution and transferred to a reagent bottle. Sodium phosphate buffer $(0.05 \mathrm{M}, \mathrm{pH} 7)$ and $0.5 \mathrm{M}$ Sodium chloride (SRL) were prepared for amylase extraction and assay. Stock standard solution (SQ, QUALIGENS fine chemicals, $0.01 \%$ ): was prepared by dissolving $180 \mathrm{mg}$ of maltose in $100 \mathrm{ml}$ of distilled water for standard maltose curve.

\subsubsection{Standard Maltose Curve}

Firstly standard maltose curve was prepared before performing amylase assay.For $\beta$-amylase test, standard maltose curve was prepared. Six clean test tubes were taken and labeled from T1 to T5.One test tube served as Blank. Firstly maltose was added in increasing order like $0.2,0.4$, $0.6,0.8$ and $1.0 \mathrm{ml}$ in each test tube and volume was made up to $2 \mathrm{ml}$ by adding distilled water only. The blank was prepared by adding $2 \mathrm{ml}$ of distilled water only. After that $1 \mathrm{ml}$ of DNS reagent was added to all the six test tubes and mixed well. All the test tubes were covered with aluminum foil and kept in boiling water bath for 5 minutes. Now test tubes were removed and allowed to cool. Absorbance was measured at $540 \mathrm{~nm}$ using colorimeter and this reading was proportional to the amount of maltose present (table no. 8).

\subsubsection{Extraction of Seed Amylase}

Amylase was extracted from $5 \mathrm{gm}$ of germinated seeds kept at different temperature. Extraction of the Enzyme is done in cold at $0-4{ }^{0}$ C. $500 \mathrm{mg}$ of washed germinating seeds in a chilled pestle and mortar was macerated with $5 \mathrm{ml}$ of $0.05 \mathrm{M}$ phosphate buffer ( $\mathrm{pH} 7.0$ ) containing $0.5 \mathrm{M} \quad \mathrm{NaCl}$. Homogenate was centrifuged at $10,000 \mathrm{rpm}$ for $15 \mathrm{~min}$ in a refrigerated centrifuge at $4{ }^{0} \mathrm{C}$. Then supernatant was decanted and used as the enzyme preparation (S.K.Sawney, Randhir Singh, 1996).

\subsubsection{Enzyme Assay}

The two test tubes were taken control and experiment; $1 \mathrm{ml}$ of starch and $1 \mathrm{ml}$ of enzyme is pipetted in to them respectively. In one of the test tubes, the reaction was terminated immediately by adding $2 \mathrm{ml}$ of DNS (dinitrosalicyclic acid) reagent. The other test tubes were incubated at $37^{\circ} \mathrm{C}$ for 15 minutes and then $1 \mathrm{ml}$ of sodium potassium tartrate was added to each of the test tubes. Then both tubes were cooled under running tap water and volume was made up to $10 \mathrm{ml}$ with distilled water. Colorimeter was set to zero absorbance at $570 \mathrm{~nm}$ and absorbance was recorded of the test. This amylase test was repeated on 6th day (refer table number 9 and 10).

\subsection{Catalase}

\subsubsection{Preparation of the Reagents}

$50 \mathrm{ml}$ of a $5 \%$ aqueous solution of potassium dichromate in distilled water was prepared. $150 \mathrm{ml}$ of glacial acetic acid was slowly added to this. The resulting solution in a $250 \mathrm{ml}$ reagent bottle was placed and set aside. The prepared liquid was toxic and corrosive.0.2M solution of hydrogen peroxide was prepared. It was given in the bottle that $1 \mathrm{M}=34.01 \mathrm{~g} / \mathrm{L}$ so, $2 \mathrm{M}=68.02 \mathrm{~g} / \mathrm{L}$, therefore $0.2 \mathrm{M}=6.80 \mathrm{~g} / \mathrm{L}$. So in $100 \mathrm{ml}$ of water $0.6802 \mathrm{gm}$ was added. It was given $30 \%$ of $\mathrm{H}_{2} \mathrm{O}_{2}$ in $100 \mathrm{ml}$,so it was $30 \mathrm{gm}$ in $100 \mathrm{ml}$. Therefore $2.2673 \mathrm{ml}$ of $\mathrm{H}_{2} \mathrm{O}_{2}$ in $100 \mathrm{ml}$ of distilled water was added and used in the experiment.About $250 \mathrm{ml}$ of 0.01Mphosphate buffer, pH 7.0 was prepared. Enzymes are generally the most stable in a solution. The standard curve using 6 different test tubes containing increasing amounts of $\mathrm{H}_{2} \mathrm{O}_{2}$ (39.98 to 202.29 micromoles) were taken. To each of these $2 \mathrm{~mL}$ of the dichromate / acetic acidreagent was added. When a blue precipitate forms in each, each test tube was heated for 10 minutes in a boiling water bath to decomposethe blue precipitate. This will leave a green solution of chromic acetate. They were cooled to room temp and in each tube enough distilled water was added to make the volume up to $3 \mathrm{ml} .3 \mathrm{~mL}$ contents of first test tubes were transferred to a clean cuvette and the absorbance was measured at 570 nanometers in the colorimeter. This process was repeated for the remaining five tubes, using a cleaned cuvette each time.Using the data obtained, graph of absorbance at $570 \mathrm{~nm}$ (y-axis) versus micromoles of $\mathrm{H}_{2} \mathrm{O}_{2}$ in the cuvette (x-axis) was plotted. A straight line was obtained as standard curve (refer table no 12).

\subsubsection{Catalase Preparation}

Before catalase preparation reagents should be prepared and standard curve should be done. Otherwise enzymes, once freed from their native environment, tend to lose their activity. Enzyme was extracted from the seeds, using a buffer at physiological $\mathrm{pH}$ and cold. 5 gram of seeds was weighed from normal room temperature, $3^{\circ} \mathrm{C}$ and $-19^{\circ} \mathrm{C}$. These seeds exposed to different temperatures were grinded in the mortar and pestle using chilled $0.01 \mathrm{M}$ phosphate buffer. Grinded seed extracts were transferred in the centrifuge tube and were centrifuged at $10,000 \mathrm{rpm}$ for 15 minutes at $24^{\circ} \mathrm{C}$ in a centrifuge rotor. The supernatant of each tube were transferred to fresh test tubes and were diluted.

\subsubsection{Enzyme Dilution}

This is necessary to get the enzyme concentration within a range that can be measured properly by the method. Too much enzyme will act so rapidly that there won't be enough $\mathrm{H}_{2} \mathrm{O}_{2}$ left to detect with the colorimetric assay. The supernatant were diluted to $10 \mathrm{X}$ buffer.

\subsubsection{The Enzyme Assay}

Graph of absorbance at $570 \mathrm{~nm}$ vs. micromoles of $\mathrm{H}_{2} \mathrm{O}_{2}$ was already made by that aliquots of enzyme preparation to 
test how much $\mathrm{H}_{2} \mathrm{O}_{2}$ the enzyme destroys in various time intervals were used. When proper dilution for the enzyme was found, then following procedures were followed-

Reaction mixture was prepared by adding $4 \mathrm{ml}$ of a $0.2 \mathrm{M}$ solution in a flask in which $5 \mathrm{ml}$ of phosphate buffer was added. $1 \mathrm{ml}$ of diluted enzyme preparation was added. 1.0 $\mathrm{ml}$ of this reaction mixture was withdrawn and injected it into $2.0 \mathrm{ml}$ of Dichromate / acetic acid reagent. The goal here is to halt the enzymatic reaction completely. Using different test tubes, this procedure was repeated at 60 second intervals. Each test tube was heated for 10 minutes in a boiling water bath to decompose the blue precipitate and produce a green solution. The absorbance was measured at 570 nanometers in the colorimeter. Using the "standard curve", how much $\mathrm{H}_{2} \mathrm{O}_{2}$ was left in the solution was determined when the enzyme was stopped with acetic acid. This procedure was performed on seeds with two days of exposure of cold temperature and on five days of exposure of cold temperature (Sinha, A.K ,1972)(refer table no 13 and 14).

\section{Result and Discussion}

\subsection{Cold Stress on Germination}

\subsubsection{Germination Percentage}

The highest no of germinated seeds was found at normal room temperature. The germination percentage was highest in normal room temperature, at $3^{\circ} \mathrm{C}$ temperature it was moderate and at $-19^{\circ} \mathrm{C}$ temperature due to extreme chilling condition there was no growth hence no germination percentage followed by table no 1 , graph no 1 .

Table 1. showing germination percentage at normal temperature, $3^{\circ} \mathrm{C}$ and $19^{\circ} \mathrm{C}$.

\begin{tabular}{llll}
\hline Date & Germination percentage & & \\
\hline & $\begin{array}{l}\text { At normal room temperature (not } \\
\text { exposed to cold stress) }\end{array}$ & AT 3 ${ }^{\circ} \mathbf{C}$ & AT -19 ${ }^{\circ} \mathbf{C}$ \\
\hline Day 1 & 20 & - & - \\
Day 3 & 60 & 10 & - \\
Day 5 & 76.6 & 16.6 & - \\
Day 7 & 83.3 & 33.3 & - \\
Day 10 & 93.3 & 46.6 & - \\
Day 12 & 96.33 & 80 & - \\
Day 15 & 96.33 & 86.6 & - \\
\hline
\end{tabular}

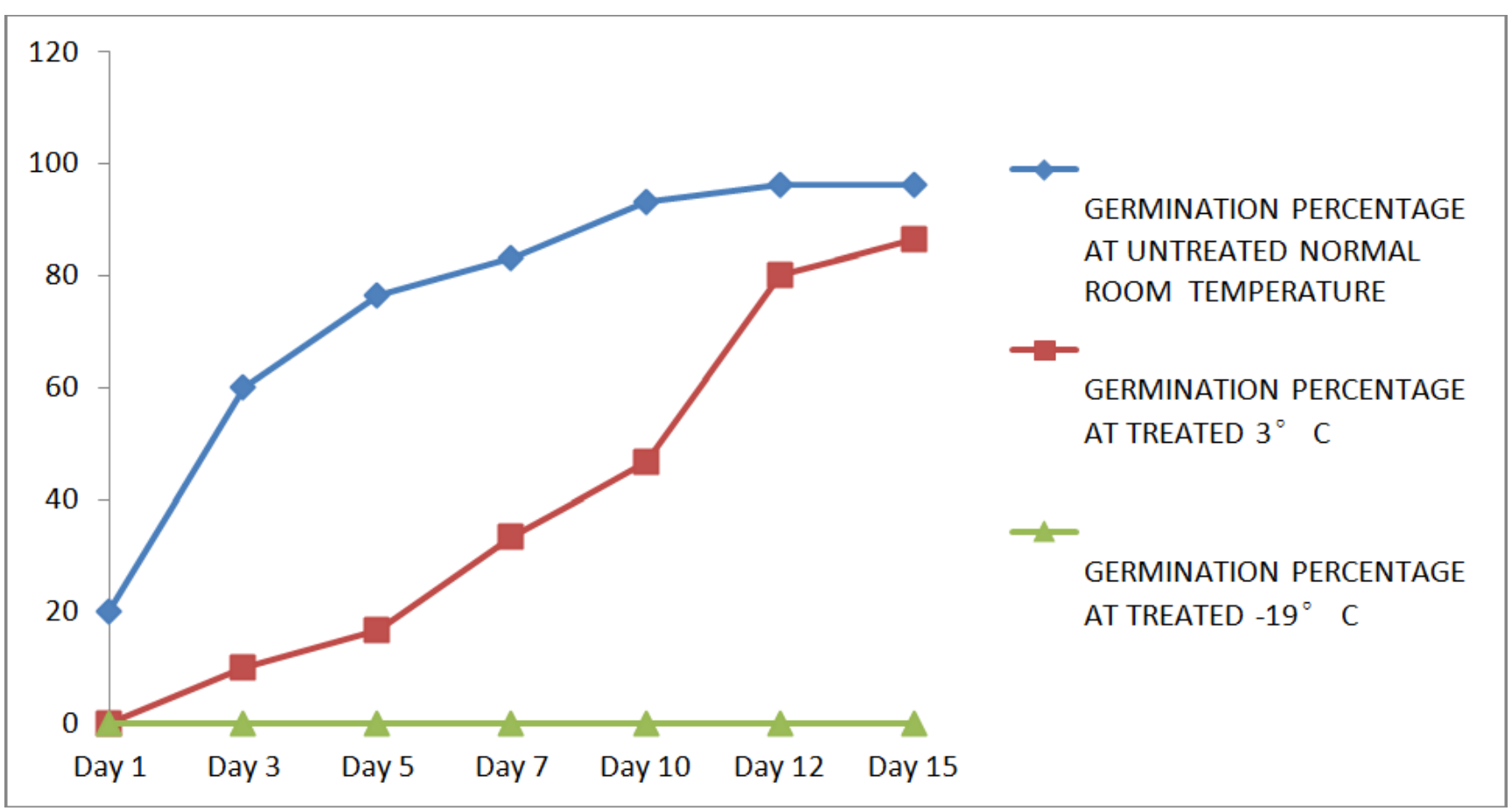

Graph 1. showing germination percentage at normal temperature, $3^{\circ} \mathrm{C}$ and $-19^{\circ} \mathrm{C}$.

\subsubsection{Germination Rate}

The highest no of germinated seeds was found at normal room temperature. The germination rate was highest in normal room temperature, at $3^{\circ} \mathrm{C}$ temperature it was moderate and at $-19^{\circ} \mathrm{C}$ temperature due to extreme chilling condition there was no growth hence no germination rate followed by table no 2, graph no 2 .

Table 2. showing germination rate at normal temperature, $3{ }^{\circ} \mathrm{C}$ and $-19^{\circ} \mathrm{C}$.

\begin{tabular}{lll}
\hline At normal room temperature & AT $\mathbf{3}^{\circ} \mathbf{C}$ & AT $-19^{\circ} \mathbf{C}$ \\
\hline 48.72 & 32.92 & - \\
\hline
\end{tabular}




\section{GERMINATION RATE}

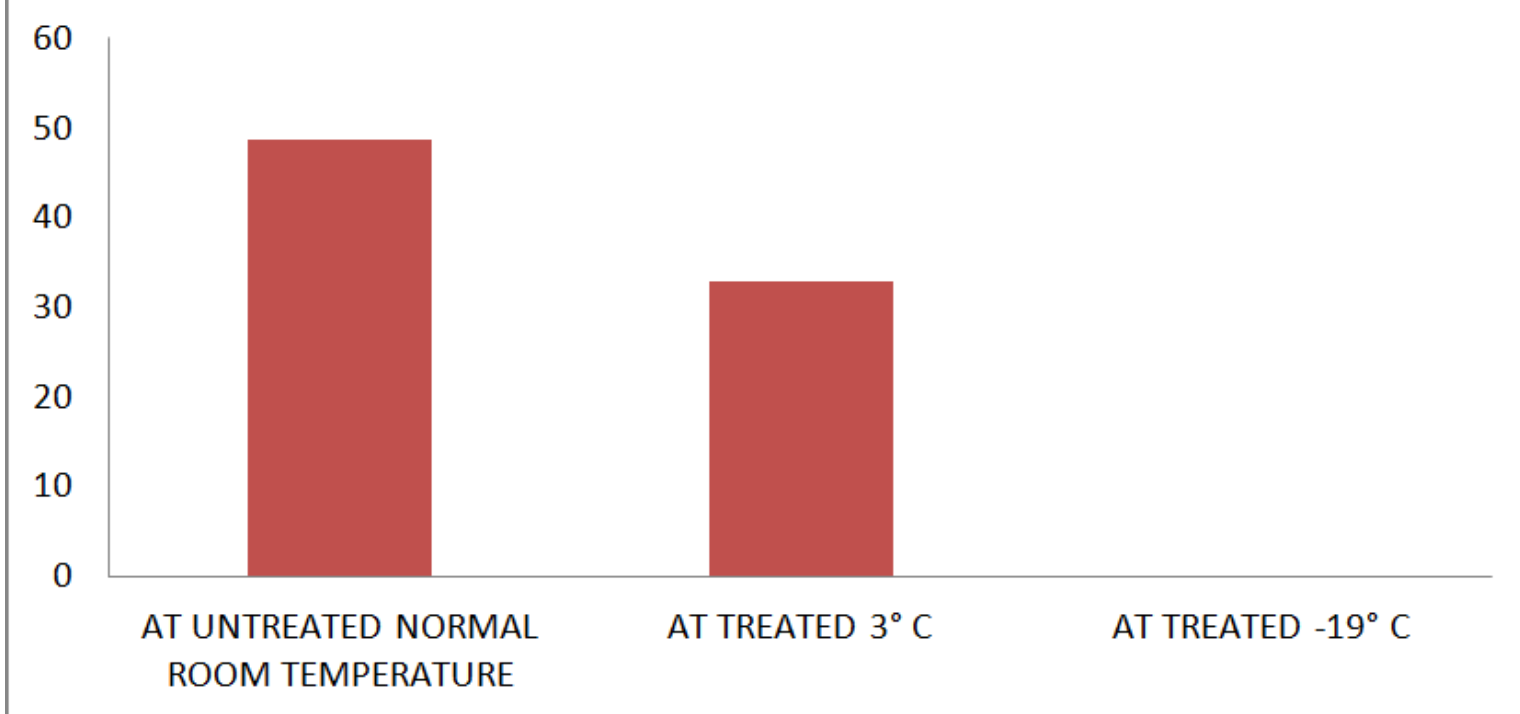

Graph 2. Showing germination rate at normal temperature, $3^{\circ} \mathrm{C}$ and $-19^{\circ} \mathrm{C}$

\subsubsection{Seed Vigour}

The highest no of germinated seeds was found at normal room temperature. The vigour index was highest in normal room temperature, at $3^{\circ} \mathrm{C}$ temperature it was moderate and at $-19^{\circ} \mathrm{C}$ temperature due to extreme chilling condition there was no growth hence no seed vigour index followed by table no 3 , graph no 3 and 4.

Table 3. showing seed vigour index at normal temperature, $3^{\circ} \mathrm{C}$ and $-19^{\circ} \mathrm{C}$.

\begin{tabular}{|c|c|c|c|}
\hline & Germination Percentage(a) & Shoot Length(b) in mm & Seed Vigour Index $\left(a^{*} b\right)$ \\
\hline \multicolumn{4}{|l|}{ Day 1} \\
\hline At Normal Room temperature & 20 & 10.16 & 203.2 \\
\hline At $3^{\circ} \mathrm{C}$ & - & - & - \\
\hline At $-19^{\circ} \mathrm{C}$ & - & - & - \\
\hline \multicolumn{4}{|l|}{ Day 3} \\
\hline At Normal Room temperature & 60 & 25.4 & 1524 \\
\hline At $3^{\circ} \mathrm{C}$ & 10 & 3.33 & 33.3 \\
\hline At $-19^{\circ} \mathrm{C}$ & - & - & - \\
\hline \multicolumn{4}{|l|}{ Day 5} \\
\hline At Normal Room temperature & 76.6 & 28.3 & 2167.78 \\
\hline At $3^{\circ} \mathrm{C}$ & 16.6 & 4.8 & 79.68 \\
\hline At $-19^{\circ} \mathrm{C}$ & - & - & - \\
\hline \multicolumn{4}{|l|}{ Day 7} \\
\hline At Normal Room temperature & 83.3 & 32.3 & 2690.59 \\
\hline At $3^{\circ} \mathrm{C}$ & 33.3 & 6.5 & 216.45 \\
\hline At $-19^{\circ} \mathrm{C}$ & - & - & - \\
\hline \multicolumn{4}{|l|}{ Day 10} \\
\hline At Normal Room temperature & 93.3 & 38.21 & 3564.99 \\
\hline At $3^{\circ} \mathrm{C}$ & 46.6 & 7.7 & 358.82 \\
\hline At $-19^{\circ} \mathrm{C}$ & - & - & - \\
\hline \multicolumn{4}{|l|}{ Day 12} \\
\hline At Normal Room temperature & 96.66 & 40.2 & 3885.732 \\
\hline At $3^{\circ} \mathrm{C}$ & 80 & 11.7 & 936 \\
\hline At $-19^{\circ} \mathrm{C}$ & - & - & - \\
\hline \multicolumn{4}{|l|}{ Day 15} \\
\hline At Normal Room temperature & 96.66 & 40.5 & 3914.73 \\
\hline At $3^{\circ} \mathrm{C}$ & 93.3 & 29.5 & 2752.35 \\
\hline At $-19^{\circ} \mathrm{C}$ & - & - & - \\
\hline
\end{tabular}




\section{SHOOT LENGTH(b) in $\mathrm{mm}$}

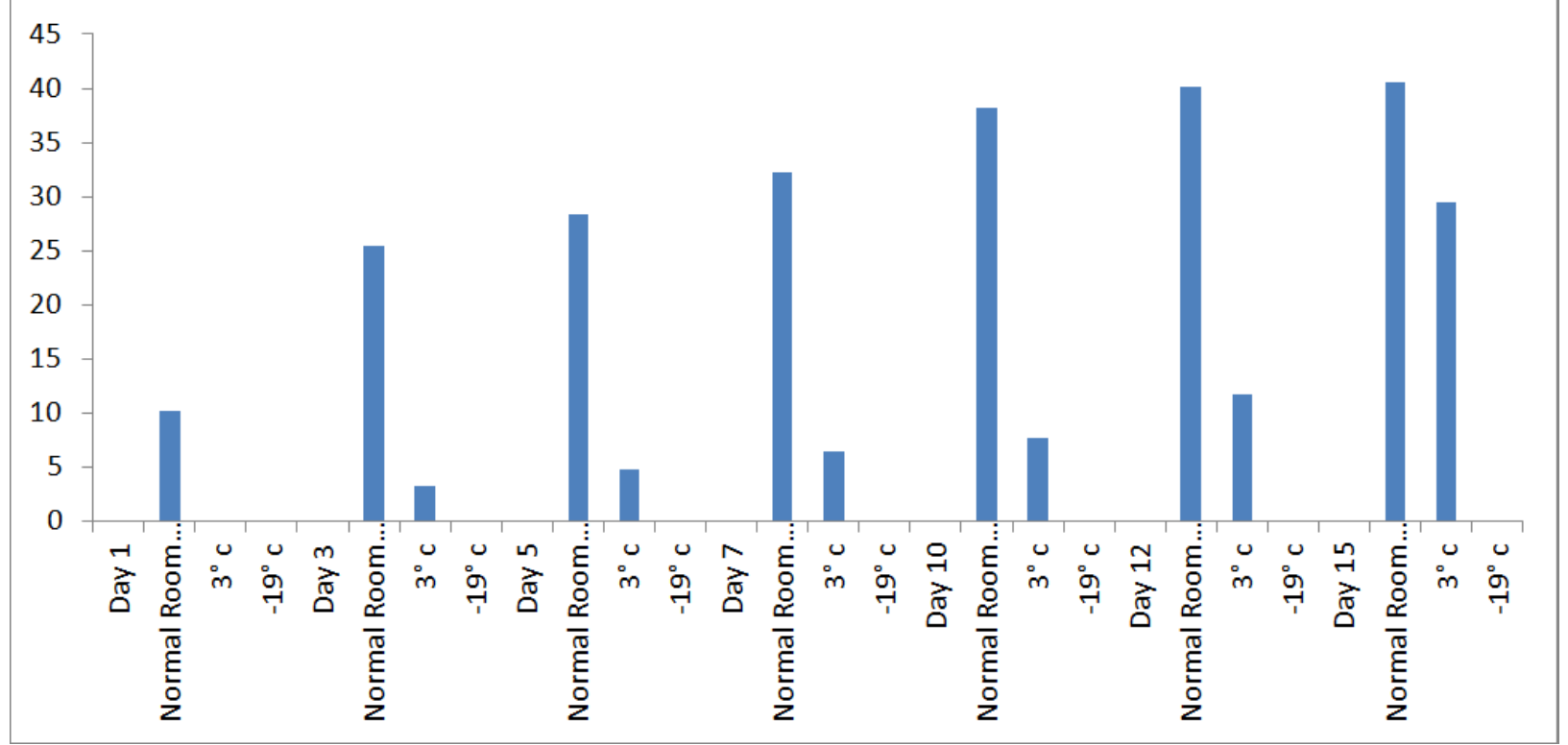

Graph 3. showing shoot length (mm) at normal temperature, $3^{\circ} \mathrm{C}$ and $-19^{\circ} \mathrm{C}$.

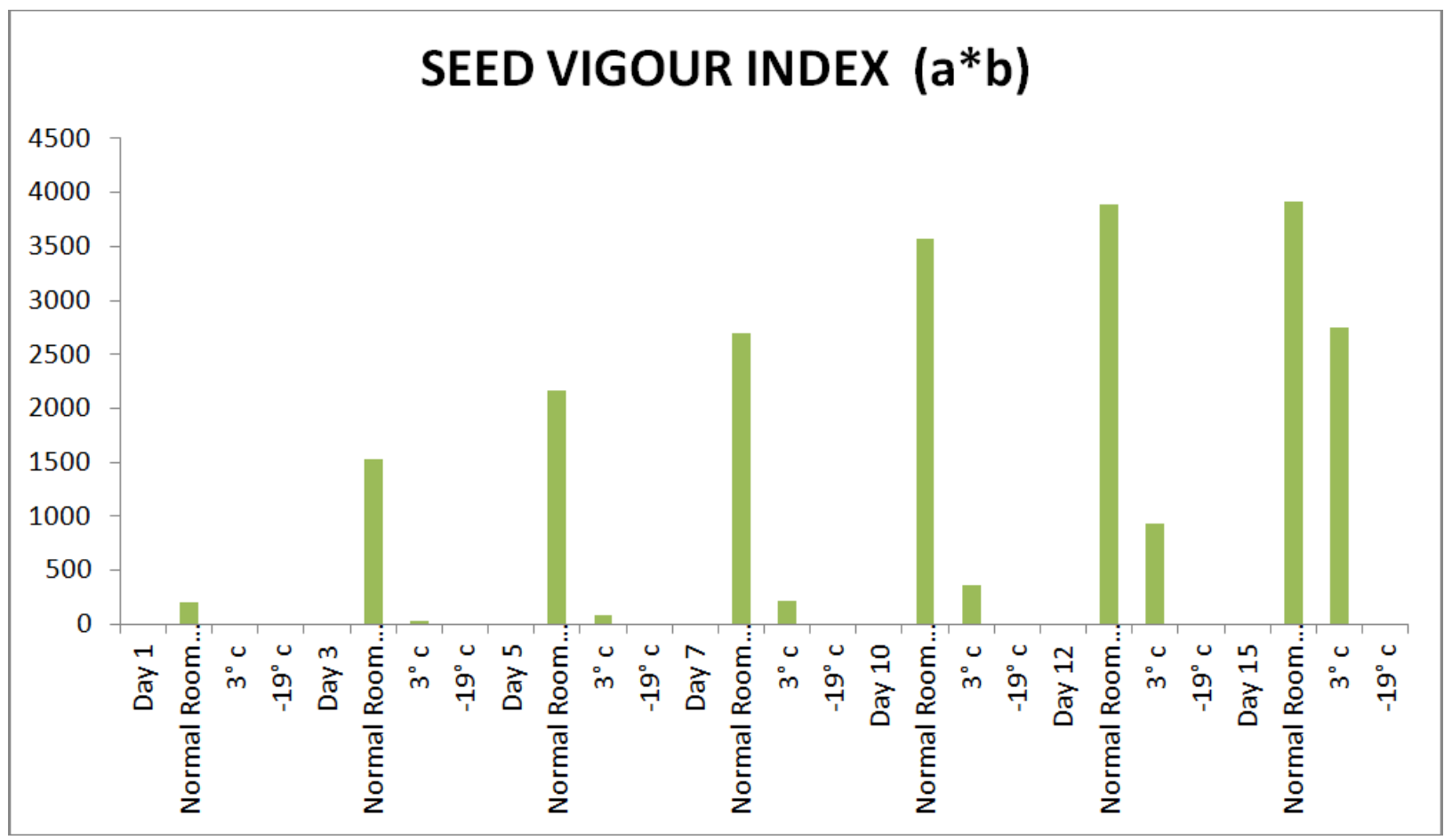

Graph 4. showing seed vigour index at normal temperature, $3^{\circ} \mathrm{C}$ and $-19^{\circ} \mathrm{C}$.

\subsubsection{Germination Index}

The highest no of germinated seeds was found at normal room temperature. The germination index was highest in normal room temperature, at $3^{\circ} \mathrm{C}$ temperature it was moderate and at $-19^{\circ} \mathrm{C}$ treated temperature due to extreme chilling condition there was no growth hence no germination index followed by table no 4 and graph no 5 .

Table 4. showing germination index at normal temperature, $3^{\circ} \mathrm{C}$ and $-19^{\circ} \mathrm{C}$ 


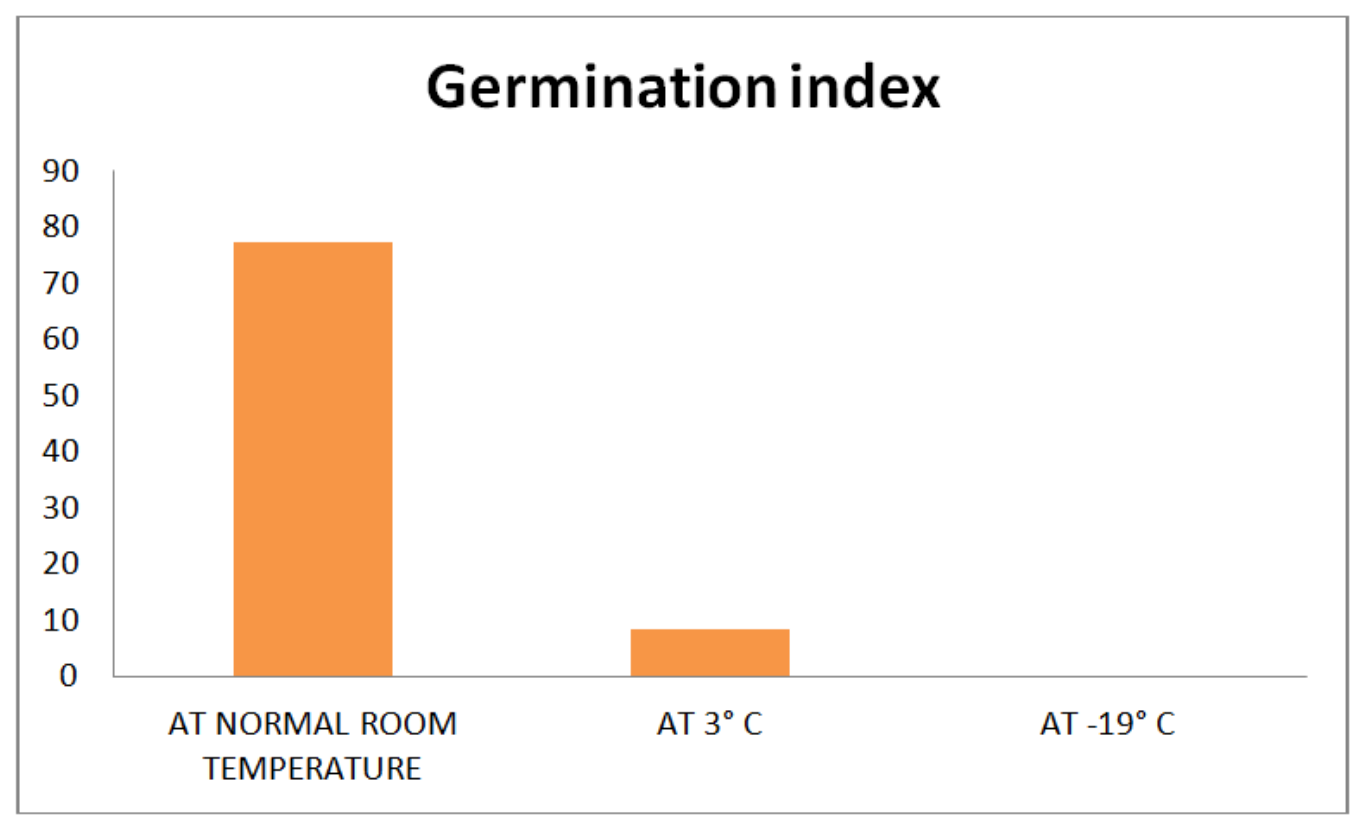

Graph 5. showing germination index at normal temperature, $3^{\circ} \mathrm{C}$ and $-19^{\circ} \mathrm{C}$.

\subsubsection{Discussion}

Cold acclimation is a universal phenomenon in chillingtolerant plants. Bean seeds were kept to survive at a lower temperature of $3^{\circ} \mathrm{C}$ and $-19^{\circ} \mathrm{C}$. Overviewing these results, chilling-sensitive plants was achieved by exposure to around or above the threshold temperature that caused chilling injury for several days. However, whether chilling acclimation can be achieved by exposure to under the threshold chilling temperature, even as low as $3^{\circ} \mathrm{C}$, which was generally known as the temperature of severe chilling injury, hasn't been documented. In the present study, we found that coldshock at $3^{\circ} \mathrm{C}$ and $-19^{\circ} \mathrm{C}$ for several days could significantly induce chilling tolerance of seedlings and investigated the changes of antioxidant enzyme activities after the cold-shock and chilling stress (Li et al .,2011).

Figures: The figures shown below are showing the germination of the Bean Seeds (Phaseolusvulgaris 1) on different days at different temperatures i.e., normal temperature, $3^{\circ} \mathrm{C}$ and at $-19^{\circ} \mathrm{C}$

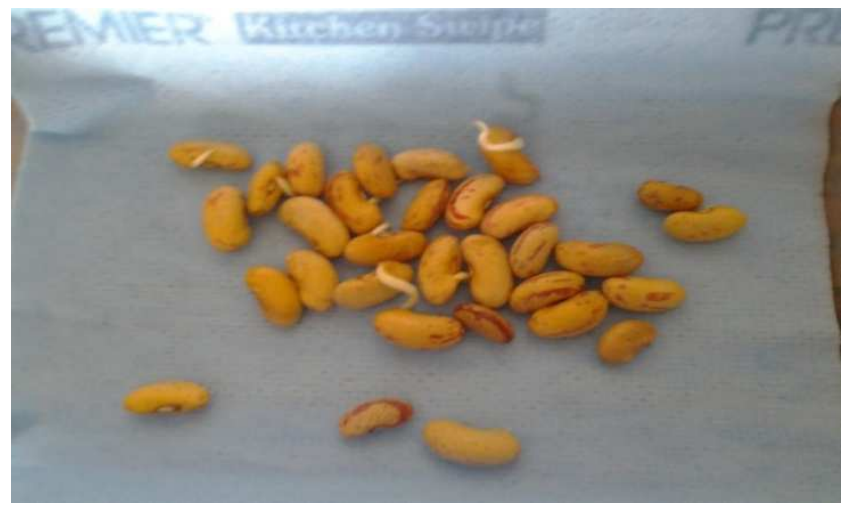

Figure 3. At Normaltemp. On day 1.

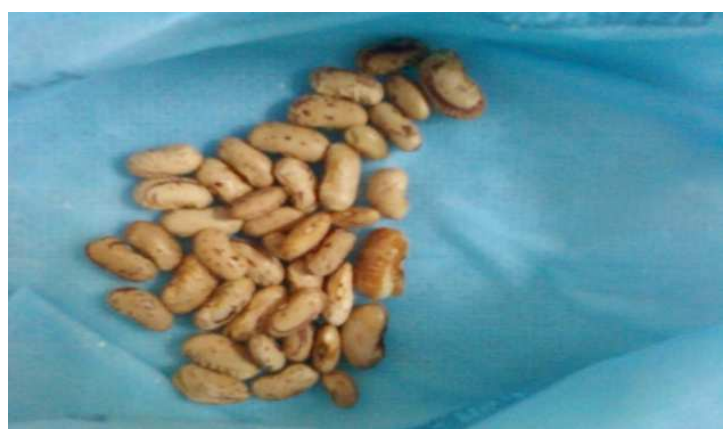

Figure 4. At $3{ }^{\circ} \mathrm{C}$ On day 1.

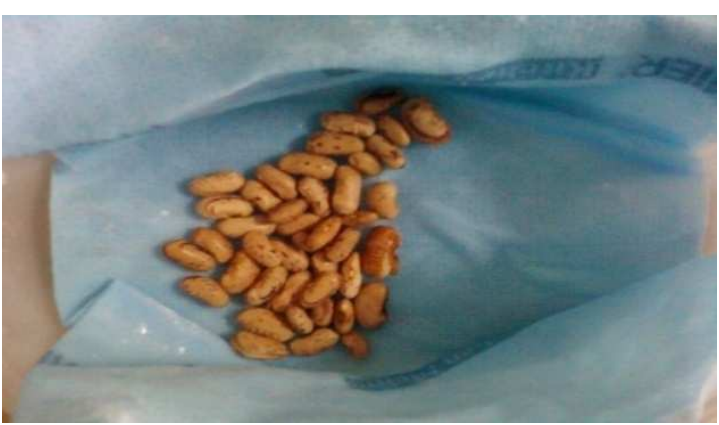

Figure 5. At $-19^{\circ} \mathrm{C}$ on day 1.

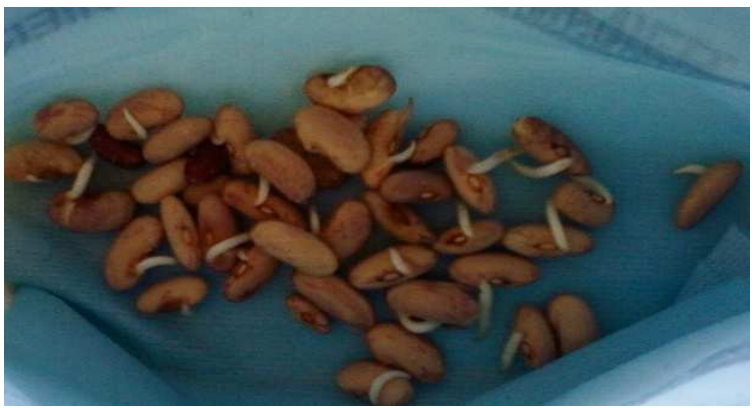

Figure 6. Atnormaltemp.On $3^{\text {rd }}$ day. 


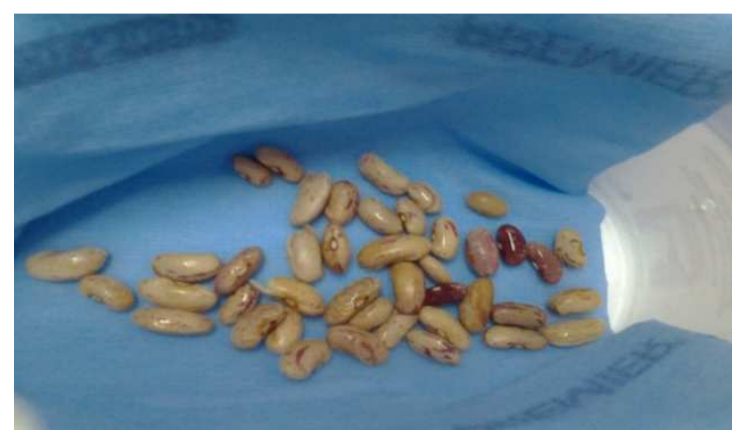

Figure 7. At $3^{\circ} \mathrm{C}$ on $3^{\text {rd }}$ day.

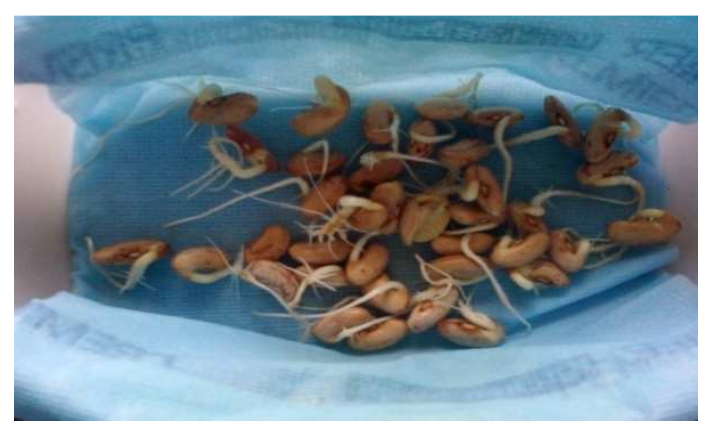

Figure 8. At normal temp. On $5^{\text {th }}$ day.

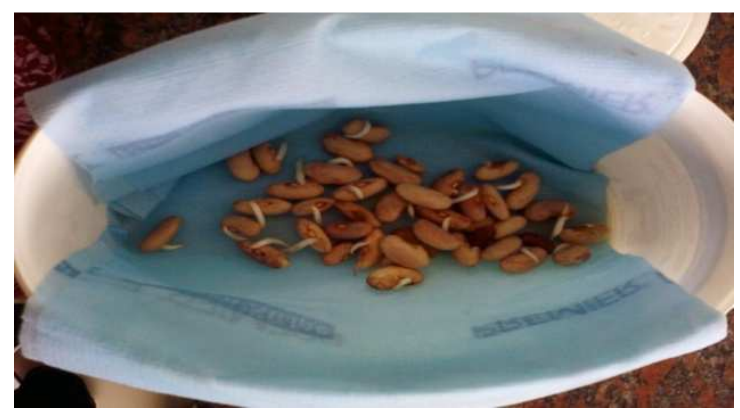

Figure 9. At $3^{\circ} \mathrm{C}$ on $5^{\text {th }}$ day.

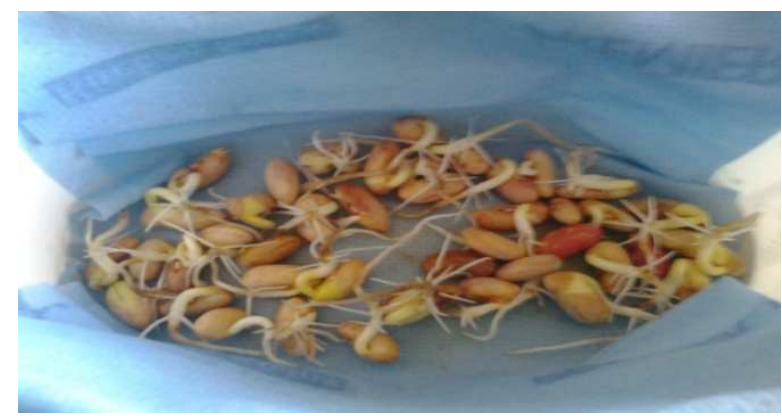

Figure 10. Atnormal temp. On $7^{\text {th }}$ day.

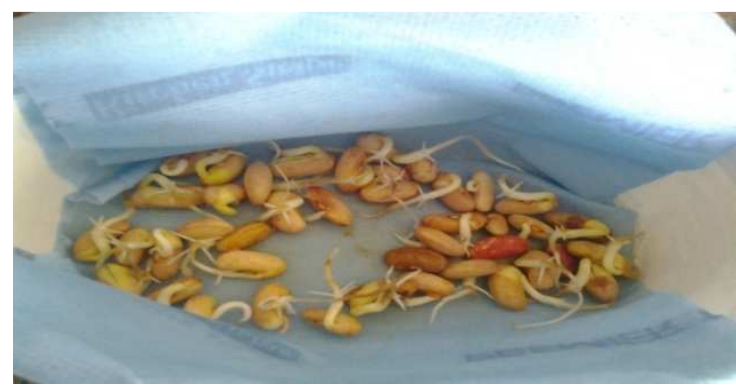

Figure 11. At $3^{\circ} \mathrm{C}$ On $7^{\text {th }}$ day.

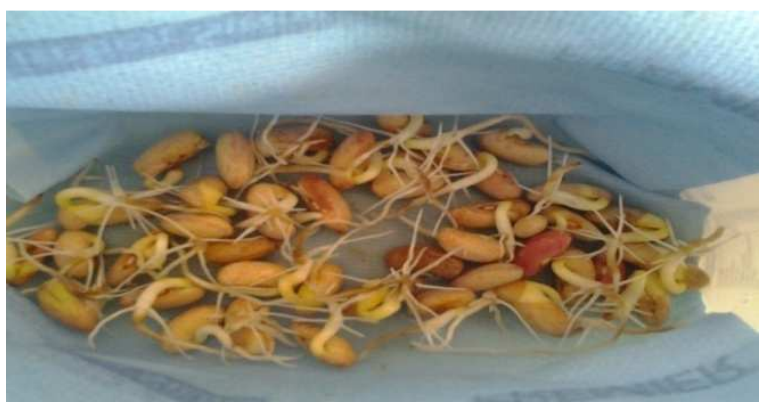

Figure 12. At normal temp. On $10^{\text {th }}$ day.

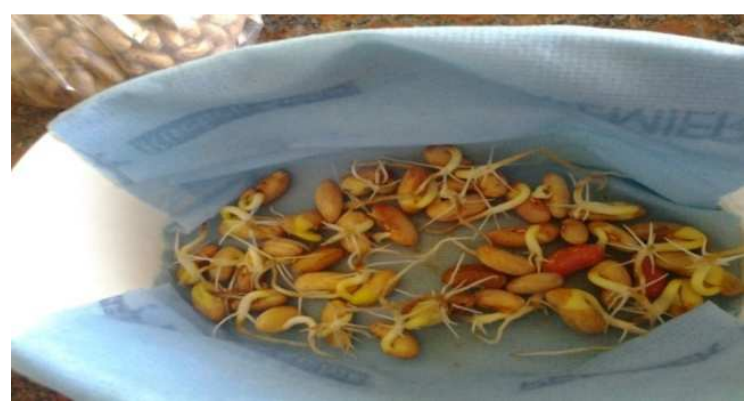

Figure 13. At $3^{\circ} \mathrm{C}$ On $10^{\text {th }}$ day.

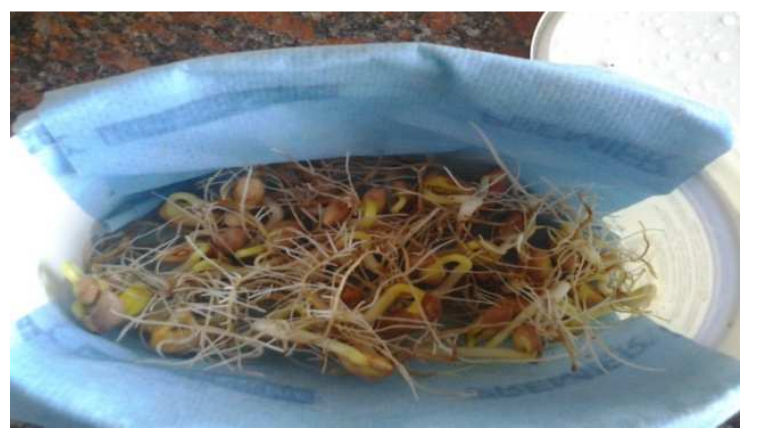

Figure 14. At normal temp.On $12^{\text {th }}$ day.

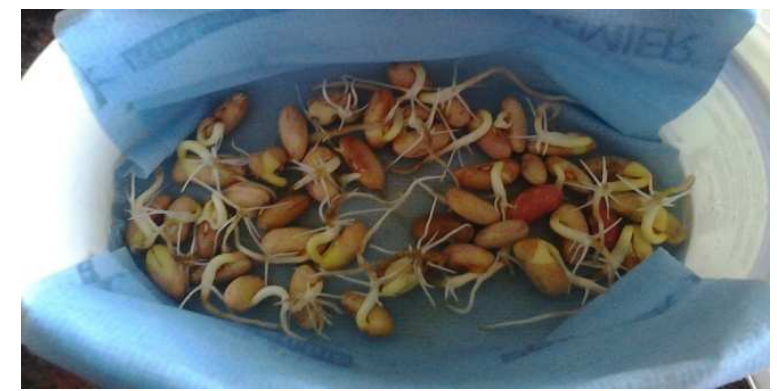

Figure 15. At $3^{\circ} \mathrm{C}$ On $12^{\text {th }}$ day.

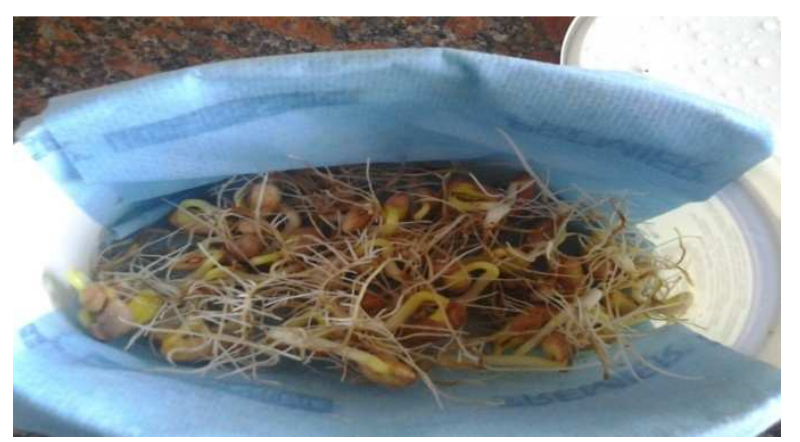

Figure 16. At normal temp.On $15^{\text {th }}$ day . 


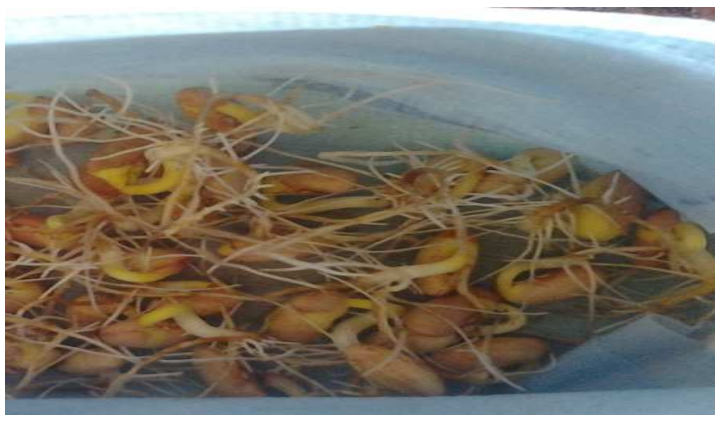

\subsection{For Respiration Response}

Respiration of seeds in normal room temperature is more because it is respiring continuously till one week, at $3^{\circ} \mathrm{C}$ respiration rate was higher earlier but at 5 th day it stopped respiring and at $-19^{\circ} \mathrm{C}$ it respire one day then stopped. Followed by Table no 5 and Graph no 6.

Figure 17. At $3^{\circ} \mathrm{C}$ On $15^{\text {th }}$ day.

Table 5. showing the water level in beaker at normal temperature, $3^{\circ} \mathrm{C},-19^{\circ} \mathrm{C}$.

\begin{tabular}{llll}
\hline & Water level in beaker at normal room temp $(\mathbf{c m})$ & Water level in beaker at $\mathbf{3}^{\circ} \mathbf{C}(\mathbf{c m})$ & Water level in beaker at $\mathbf{- 1 9}{ }^{\circ} \mathbf{C}(\mathbf{c m})$ \\
\hline $1^{\text {st }}$ day & 5 & 5 & 5 \\
$2^{\text {nd }}$ day & 4.6 & 4.0 & 3.9 \\
$3^{\text {rd }}$ day & 3.8 & 3.5 & 3.9 \\
$4^{\text {th }}$ day & 3.4 & 3.3 & 3.9 \\
$5^{\text {th }}$ day & 3 & 3.0 & 3.9 \\
$6^{\text {th }}$ day & 2.7 & 2.8 & 3.9 \\
$7^{\text {th }}$ day & 2.4 & 2.8 & 3.9 \\
\hline
\end{tabular}

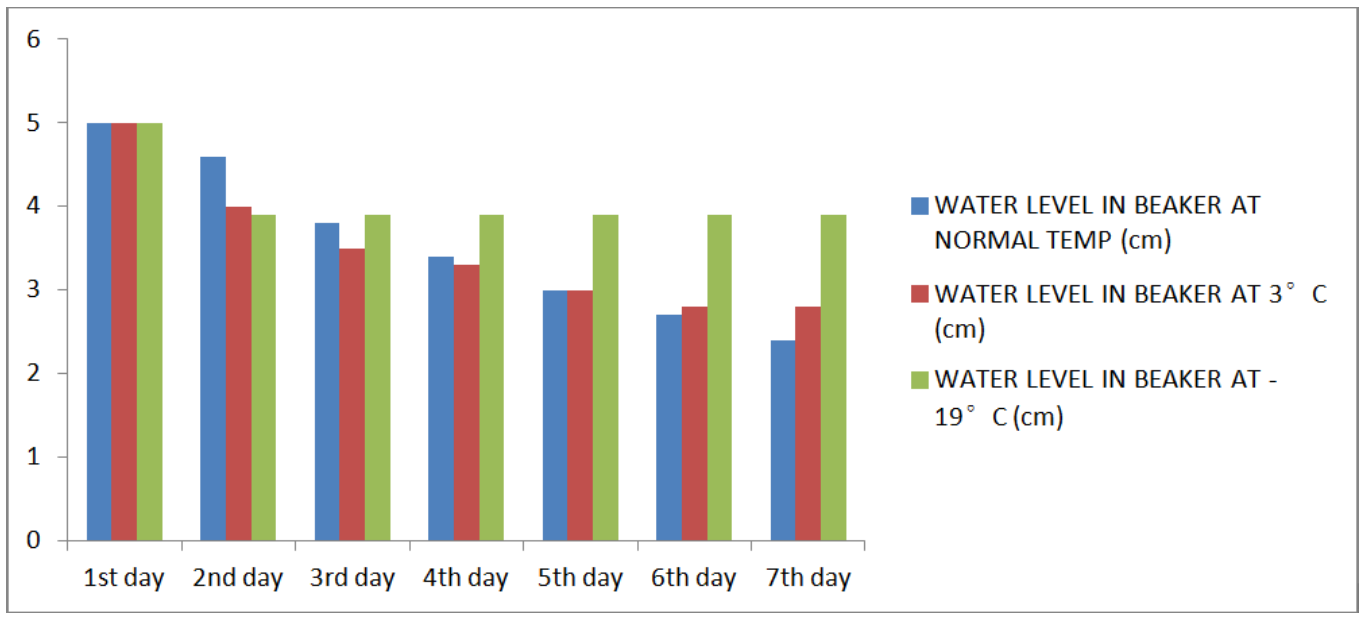

Graph 6. Showing the water level in beaker at normal temperature, $3^{\circ} \mathrm{C},-19^{\circ} \mathrm{C}$.

Figures Showing Respiration activity setup and Water level on the First day and after 1 week for checking respiration activity

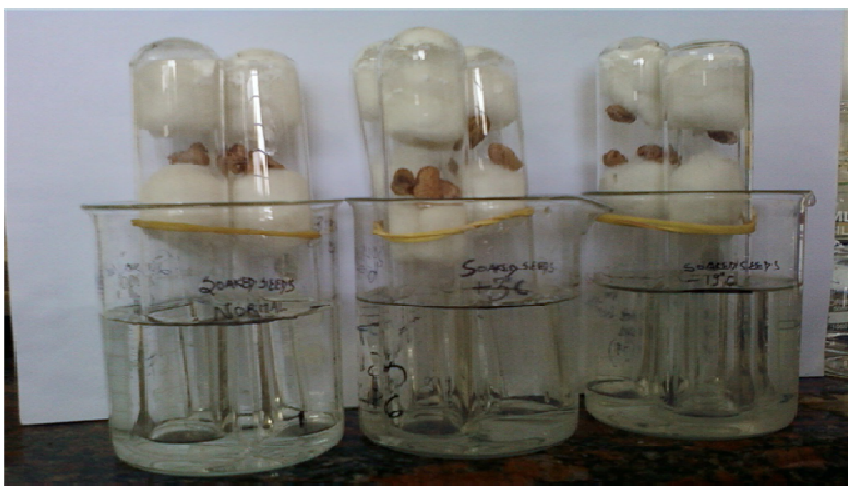

Figure 18. showing initial water level in the beaker on the First day kept at normal temperature and at $3{ }^{\circ} \mathrm{C}$ and $-19^{\circ} \mathrm{C}$.

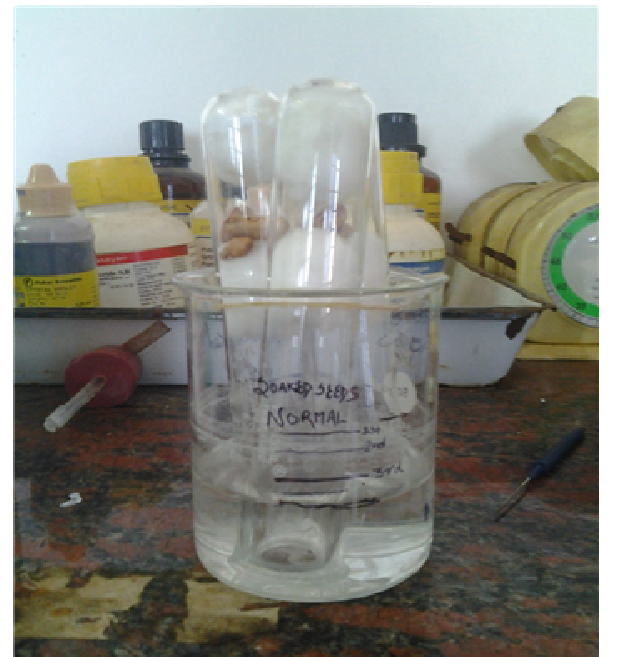

Figure 19. showing water level in the beaker after 1 week kept at normal temperature. 


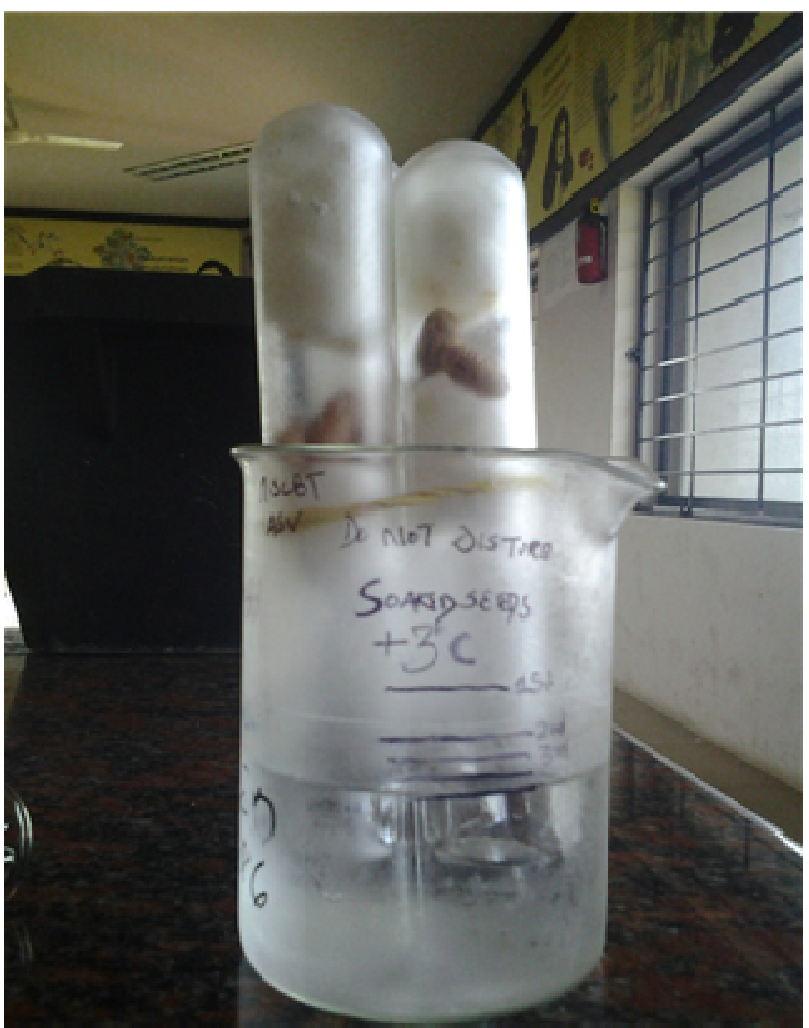

Figure 20. Showing water level in the beaker after 1 week kept at $3^{\circ} \mathrm{C}$

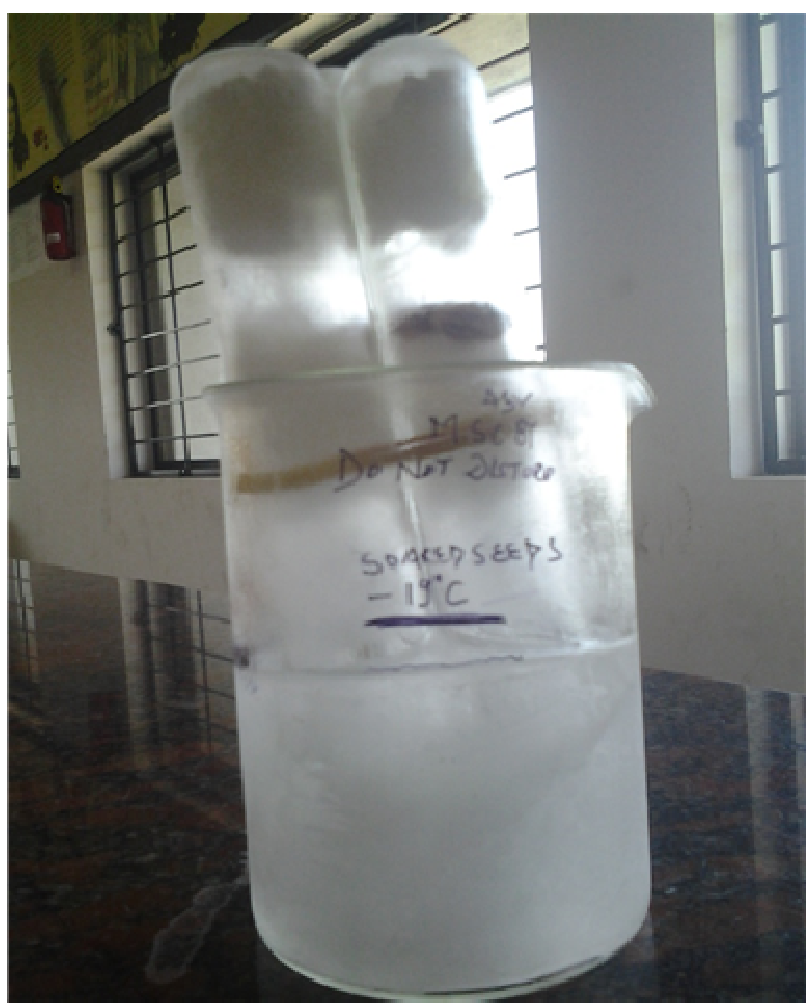

Figure 21. Showing water level in the beaker after 1 week kept at $-19^{\circ} \mathrm{C}$

\subsubsection{Discussion}

Parallel observations have been made on changes in respiration rate of Phaseolus vulgaris $\mathrm{L}$ at room temperature, $3^{\circ} \mathrm{C}$ and $-19^{\circ} \mathrm{C}$. While oxygen rises to a peak between the third and fifth days in set up of room and $3^{\circ} \mathrm{c}$. Respiration activity falls or stop from 24 hours onwards in - $19^{\circ} \mathrm{C}$. The expression of respiration patterns of the three set of respiration activity of bean under room temperature, were different from those under $3^{\circ} \mathrm{C}$ and $-19^{\circ} \mathrm{C}$. Seeds are the most stress-tolerant form of higher plants, and, accordingly, they were found to harbor extremely resistant to temperature extremes. Because respiration is the driving force that powers germination, a high level of mitochondrial stress tolerance certainly contributes to the vigor of germinating seeds in the environment. The respiration response under chilling temperature might be an important factor contributing to chilling susceptibility of bean seeds. Respiration rates of plant cells are also affected by temperature and there is a linear increase in $\mathrm{O}_{2}$ uptake with temperature. In addition to short term responses, species grown at low temperatures often show higher rates of respiration than species grown at higher temperatures when measured at the same temperature .This stimulation of respiration was reported as adaptive behavior of seeds grown at cold conditions compared with related species from warmer conditions. The increased rate of respiration at low temperatures in mitochondria involves two energy dissipating systems, Alternative Oxidase (AOX) pathway and Plant Uncoupling Mitochondrial Protein (PUMP). This stimulation of respiration causes a decrease in the yield of ATP synthase which is linked to an increase in heat dissipation. These systems are also involved inremoval of Reactive Oxygen Species (ROS), because theydo not generate a proton electrochemical gradient (Maryam Madadkar.,2007).

\subsection{Conductivity}

The electrical conductivity can be used as an indicator of seed viability and presents two advantages: to provide rapid and reliable results and the technique is not destructive and can use the seeds after the conductivity test, so they can be used to produce seedlings. The present study showed that different soaking times had no effect on the results of conductivity testing of freshly collected Phaseolus vulgaris $L$ seeds, suggesting that the amount of leached matter was never below the threshold required for adequate testing. It was observed that conductivity was more at normal temperature and lesser in cold stress. But compared to $2^{\text {nd }}$ day conductivity decreased on $7^{\text {th }}$ day. Electrical conductivity testing proved to be a feasible option for viability testing of Phaseolus vulgaris L. seeds.Followed by table no

Table 6. showing the weight of soaked seeds and temperature of leachate solution at normal temperature, $3{ }^{\circ} \mathrm{C},-19^{\circ} \mathrm{C}$.

\begin{tabular}{llll}
\hline & $\begin{array}{l}\text { At normal } \\
\text { temperature }\end{array}$ & ${\text { At } 3^{\circ} \mathbf{C}}$ & $\mathbf{A t ~} \mathbf{- 1 9}^{\circ} \mathbf{C}$ \\
\hline On $2^{\text {nd }}$ day & & & \\
Weight of soaked seeds (g) & 20.18 & 20.91 & 21 \\
Temp of leachate solution & $34.7^{\circ} \mathrm{C}$ & $10^{\circ} \mathrm{C}$ & $0^{\circ} \mathrm{C}$ \\
On $7^{\text {th }}$ day & & & \\
Weight of soaked seeds $(\mathrm{g})$ & 21.2 & 21.45 & 21.56 \\
Temp of leachate solution & $35^{\circ} \mathrm{C}$ & $4^{\circ} \mathrm{C}$ & $0^{\circ} \mathrm{C}$ \\
\hline
\end{tabular}


Table 7. showing the conductivity of seeds at normal temperature, $3^{\circ} \mathrm{C},-19^{\circ} \mathrm{C}$.

\begin{tabular}{llll}
\hline & $\begin{array}{l}\text { Conductivity at } \\
\text { Normal } \\
\text { Temperature } \\
\left(\boldsymbol{\mu}{ }^{\circ} \mathbf{C}\right.\end{array}$ & $\begin{array}{l}\text { Conductivity } \\
\text { at } \mathbf{3}^{\circ} \mathbf{C} \\
(\boldsymbol{\mu} \text { siemens) }\end{array}$ & $\begin{array}{l}\text { Conductivity at } \\
-\mathbf{1 9}^{\circ} \mathbf{C} \\
(\boldsymbol{\mu} \text { siemens) }\end{array}$ \\
\hline Day 2 & 136 & 58 & 30 \\
Day 7 & 96 & 59 & 54 \\
\hline
\end{tabular}

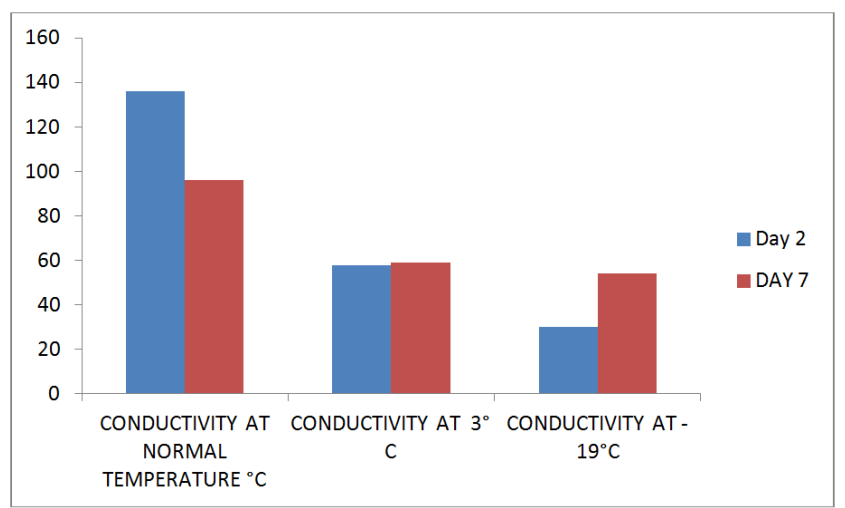

Graph 7. showing the conductivity of seeds at normal temperature, $3^{\circ} \mathrm{C}$, $19^{\circ} \mathrm{C}$.

\subsubsection{Discussion}

Based on conductivity result, different soaking times were not associated with any significant differences in conductivity results in Phaseolus vulgaris 1 seeds. As seeds lose vigor, nutrients exude from their membranes, and so low quality seeds leak electrolytes such as amino acids, organic acids while high quality seeds contains their nutrients within well structured membranes. Therefore, seeds with higher conductivity measurement are indication of low quality seeds as vice versa. Concerning the cold test, most seed lots presented standard values. Beans seed lots that present EC test values between 60 and $70 \mu \mathrm{S} \mathrm{cm}^{-1} \mathrm{~g}^{-1}$ are considered high vigor seed lots; values between 70 and $80 \mu \mathrm{S} \mathrm{cm}^{-1} \mathrm{~g}^{-1}$ are presented by intermediary vigor seed lots. On the other hand, in the United States of America, seeds with EC values higher than $150 \mu \mathrm{S} \mathrm{cm} \mathrm{cm}^{-1}$ are classified as low vigor seed lots and considered inadequate for sowing (AOSA, 1983). One of the causes for the high EC values obtained for some seed lots is, probably, the low initial seed water content, as already reported by Loeffer et al. (1998), Hampton et al. (1992) and Vieira et al. (2002). These authors observed that beans seeds having initial water contents lower than $10 \%$ usually presented higher values for the EC test, in spite of having similar standard germination and vigor evaluated by the accelerated aging test. This has been attributed to the fact that, the lower the seed moisture content, the higher the structural disorganization of cellular membranes, and the higher the loss of leachates during the initial period of seed soaking and, consequently, the higher the value of EC of the seed soaking solution, which does not mean, however, a necessarily lower seed vigor (Bewley\& Black, 1994). The effect of the initial seed water content is very difficult to be isolated and characterized, and may interact with other factors affecting EC.

\subsection{Amylase}

Table 8. maltose standard curve

Table 8. standard maltose curve.

\begin{tabular}{|c|c|c|c|c|c|c|c|}
\hline SI no. & Std.maltose solution (ml) & Amount of maltose ( $\mu$ moles) & $\mathbf{D W}(\mathrm{ml})$ & DNS(ml) & \multirow{7}{*}{$\begin{array}{l}\text { Mix and place all } \\
\text { tubes in boiling } \\
\text { water bath for } 10 \\
\text { mins and then } \\
\text { cool at room } \\
\text { temp }\end{array}$} & $\mathrm{DW}(\mathrm{ml})$ & OD at $540 \mathrm{~nm}$ \\
\hline Blank & 0.0 & 0 & 1 & 1 & & 6 & 0.0 \\
\hline $\mathrm{T} 1$ & 0.2 & 1 & 0.8 & 1 & & 6 & 0.05 \\
\hline $\mathrm{T} 2$ & 0.4 & 2 & 0.6 & 1 & & 6 & 0.15 \\
\hline $\mathrm{T} 3$ & 0.6 & 3 & 0.4 & 1 & & 6 & 0.19 \\
\hline $\mathrm{T} 4$ & 0.8 & 4 & 0.2 & 1 & & 6 & 0.30 \\
\hline $\mathrm{T} 5$ & 1.0 & 5 & 0.0 & 1 & & 6 & 0.40 \\
\hline
\end{tabular}

Observation Table 9

On $2^{\text {nd }}$ day assay

Table 9. showing amylase enzyme assay on $2^{\text {nd }}$ day for measuring activity of amylase enzyme in bean seeds at normal temperature, $3^{\circ} \mathrm{C}$ and $-19^{\circ} \mathrm{C}$.

\begin{tabular}{|c|c|c|c|c|c|c|c|c|c|c|}
\hline Sl.no. & $\begin{array}{l}\text { Enzyme } \\
\operatorname{extract}(\mathrm{ml})\end{array}$ & $\begin{array}{l}\text { Starch } \\
\text { solution(ml) }\end{array}$ & \multirow{3}{*}{$\begin{array}{l}\text { Test tube } \\
\text { containing } \\
\text { test is } \\
\text { incubate at } \\
37^{\circ} \mathrm{C} \text { for } \\
15 \text { mins }\end{array}$} & DNS(ml) & \multirow{3}{*}{$\begin{array}{l}\text { Kept in } \\
\text { boiling } \\
\text { water } \\
\text { bath for } 5 \\
\text { mins }\end{array}$} & $\begin{array}{l}\text { Na-K } \\
\text { tartarate } \\
\text { solution(ml) }\end{array}$ & \multirow{3}{*}{$\begin{array}{l}\text { Cool the } \\
\text { tubes in } \\
\text { running } \\
\text { tap water } \\
\text { and make } \\
\text { volume } \\
\text { upto } 10 \mathrm{ml} \\
\text { with DW }\end{array}$} & $\begin{array}{l}\text { OD at } 570 \\
\text { nm of } \\
\text { normal } \\
\text { temp }\end{array}$ & $\begin{array}{l}\text { OD at } 570 \\
\mathrm{~nm} \text { of } 3^{\circ} \mathrm{C}\end{array}$ & $\begin{array}{l}\text { OD at } 570 \\
\mathrm{~nm} \text { of }- \\
19^{\circ} \mathrm{C}\end{array}$ \\
\hline test & 1 & - & & 2 & & 1 & & 0.09 & 0.12 & 0.20 \\
\hline blank & - & 1 & & 2 & & 1 & & 0.0 & 0.0 & 0.0 \\
\hline
\end{tabular}

Observation Table 10

On $6^{\text {th }}$ day assay 
Table 10. showing amylase enzyme assay on $6^{\text {th }}$ day for measuring activity of amylase enzyme in bean seeds at normal temperature, $3^{\circ} \mathrm{C}$ and $-19^{\circ} \mathrm{C}$.

\begin{tabular}{|c|c|c|c|c|c|c|c|c|c|c|}
\hline & $\begin{array}{l}\text { Enzyme } \\
\operatorname{extract}(\mathrm{ml})\end{array}$ & $\begin{array}{l}\text { Starch } \\
\text { solution }(\mathrm{ml})\end{array}$ & \multirow{3}{*}{$\begin{array}{l}\text { Test tube } \\
\text { containing } \\
\text { test is } \\
\text { incubate at } \\
37^{\circ} \mathrm{C} \text { for } \\
15 \mathrm{mins}\end{array}$} & DNS(ml) & \multirow{3}{*}{$\begin{array}{l}\text { Kept in } \\
\text { boiling } \\
\text { water } \\
\text { bath for } \\
5 \text { mins }\end{array}$} & $\begin{array}{l}\text { Na-K } \\
\text { tartarate } \\
\text { solution(ml) }\end{array}$ & \multirow{3}{*}{$\begin{array}{l}\text { Cool the } \\
\text { tubes in } \\
\text { running } \\
\text { tap water } \\
\text { and make } \\
\text { volume } \\
\text { upto } 10 \mathrm{ml} \\
\text { with DW }\end{array}$} & $\begin{array}{l}\text { OD at } 570 \\
\text { nm of } \\
\text { normal } \\
\text { temp }\end{array}$ & $\begin{array}{l}\text { OD at } 570 \\
\text { nm of } 3^{\circ} \mathrm{C}\end{array}$ & $\begin{array}{l}\text { OD at } 570 \\
\text { nm of - } \\
19^{\circ} \mathrm{C}\end{array}$ \\
\hline test & 1 & - & & 2 & & 1 & & 0.03 & 0.05 & 0.06 \\
\hline blank & - & 1 & & 2 & & 1 & & 0.0 & 0.0 & 0.0 \\
\hline
\end{tabular}

On $2^{\text {nd }}$ day

From maltose curve $0.09 \mathrm{OD}$ at normal temperature on $2^{\text {nd }}$ day corresponds to $1.2 \mu$ moles/ml of maltose

Dilution factor $=10 \mathrm{x}$

Incubation time $=15 \mathrm{mins}$

Volume of enzyme taken for assay $=1 \mathrm{ml}$

Activity of enzyme $=$ ( $\mu$ moles of maltose*dilution factor $/$ weight of enzyme per gram * incubation time $=$ $1.2 * 10 / 1 * 15=0.8 \mu \mathrm{moles} / \mathrm{ml} / \mathrm{min}$

From maltose curve 0.12 OD at $3^{\circ} \mathrm{C}$ on $2^{\text {nd }}$ day corresponds to $1.45 \mu$ moles $/ \mathrm{ml}$ of maltose

Dilution factor $=10 \mathrm{x}$

Incubation time $=15$ mins

Volume of enzyme taken for assay $=1 \mathrm{ml}$

Activity of enzyme $=$ ( $\mu$ moles of maltose*dilution factor $/$ weight of enzyme per gram * incubation time $=$ $1.45 * 10 / 1 * 15=0.966 \mu \mathrm{moles} / \mathrm{ml} / \mathrm{min}$

From maltose curve 0.20 OD at $-19^{\circ} \mathrm{C}$ on $2^{\text {nd }}$ day corresponds to $2.65 \mu \mathrm{moles} / \mathrm{ml}$ of maltose

Dilution factor $=10 \mathrm{x}$

Incubation time $=15$ mins

Volume of enzyme taken for assay $=1 \mathrm{ml}$

Activity of enzyme $=$ ( $\mu$ moles of maltose*dilution factor $) /$ weight of enzyme per gram $*$ incubation time $=$ $2.65 * 10 / 1 * 15=1.766 \mu \mathrm{moles} / \mathrm{ml} / \mathrm{min}$

On $6^{\text {th }}$ day

From maltose curve 0.03 OD at normal temperature on $6^{\text {th }}$ day corresponds to $0.4 \mu \mathrm{moles} / \mathrm{ml}$ of maltose

Dilution factor $=10 \mathrm{x}$

Incubation time $=15$ mins

Volume of enzyme taken for assay $=1 \mathrm{ml}$

Activity of enzyme $=$ ( $\mu$ moles of maltose*dilution factor $) /$ weight of enzyme per gram $*$ incubation time $=$ $0.4 * 10 / 1 * 15=0.266 \mu \mathrm{moles} / \mathrm{gwt} / \mathrm{min}$

From maltose curve 0.05 OD at $3^{\circ} \mathrm{C}$ on $6^{\text {th }}$ day corresponds to $0.65 \mu \mathrm{moles} / \mathrm{ml}$ of maltose

Dilution factor $=10 \mathrm{x}$

Incubation time $=15$ mins

Volume of enzyme taken for assay $=1 \mathrm{ml}$

Activity of enzyme $=$ ( $\mu$ moles of maltose*dilution factor $) /$ weight of enzyme per gram $*$ incubation time $=$ $0.65 * 10 / 1 * 15=0.433 \mu \mathrm{moles} / \mathrm{ml} / \mathrm{min}$

From maltose curve $0.06 \mathrm{OD}$ at $-19^{\circ} \mathrm{C}$ on $6^{\text {th }}$ day corresponds to $0.8 \mu \mathrm{moles} / \mathrm{ml}$ of maltose

Dilution factor $=10 \mathrm{x}$

Incubation time $=15$ mins

Volume of enzyme taken for assay $=1 \mathrm{ml}$

Activity of enzyme $=$ ( $\mu$ moles of maltose*dilution factor)/weight of enzyme per gram $*$ incubation time $=$ $0.8 * 10 / 1 * 15=0.533 \mu \mathrm{moles} / \mathrm{ml} / \mathrm{min}$

\subsubsection{Result}

Activity of beta amylase in bean seeds (phaseolus vulgaris l)

Table 11. showing activity of amylase enzymes in bean seeds at normal temperature, $3^{\circ} \mathrm{C}$ and $-19^{\circ} \mathrm{C}$.

\begin{tabular}{llll}
\hline Days & $\begin{array}{l}\text { Activity at normal } \\
\text { room temperature } \\
(\mu \mathrm{moles} / \mathrm{ml} / \mathbf{m i n})\end{array}$ & $\begin{array}{l}\text { Activity at } \mathbf{3}^{\circ} \mathrm{C} \\
(\mu \mathrm{moles} / \mathbf{m l} / \mathbf{m i n})\end{array}$ & $\begin{array}{l}\text { Activity at } \mathbf{- 1 9}{ }^{\circ} \mathrm{C} \\
(\mu \mathrm{moles} / \mathbf{m l} / \mathbf{m i n})\end{array}$ \\
\hline $\begin{array}{l}2^{\text {nd }} \\
\text { day } \\
6^{\text {th }} \\
\text { day }\end{array}$ & 0.8 & 0.966 & 1.766 \\
\hline
\end{tabular}

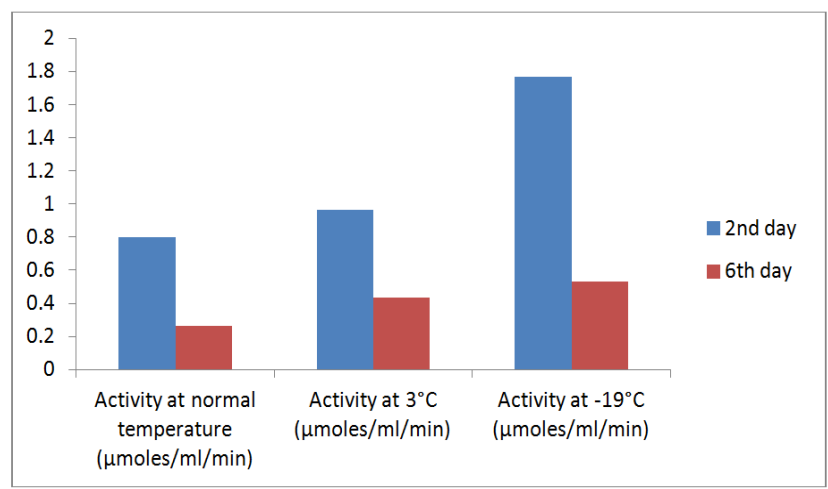

Graph 8. showing activity of amylase enzymes in bean seeds at normal temperature, $3^{\circ} \mathrm{C}$ and $-19^{\circ} \mathrm{C}$.

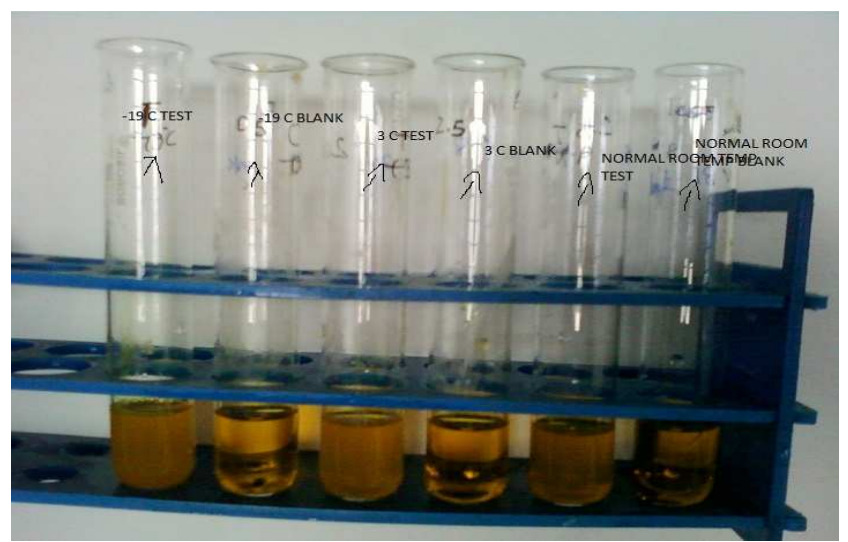

Figure 22. Amylase activity experiment.

\subsubsection{Discussion}

The amylase activity was high at $-19^{\circ} \mathrm{C}$ then at $3^{\circ} \mathrm{C}$ and room temperature respectively. The reason was that as seeds 
are stored at low temperature there is high accumulation of sugar in the seeds as compared to high temperature so it will show high starch degrading activities at low temperature (Tom Hamborg Nielsen, UtaDeiting, 1997).There are studies which supports that amylase activity increases in response to control (Md. ShahidulHaque and Md. Kamal Hossain 2011,
Shashi Sharma, Rajender Kumar Sharma, 2010).

\subsection{Catalase}

Standard $\mathrm{H}_{2} \mathrm{O}_{2}$ (Table 12)

Table 12. Standard Hydrogen Peroxide Curve.

\begin{tabular}{|c|c|c|c|c|c|c|}
\hline & $\begin{array}{l}\text { Std } \mathrm{H}_{2} \mathrm{O}_{2} \\
\text { solution(ml) }\end{array}$ & $\begin{array}{l}\text { Amount of } \\
\mathrm{H}_{2} \mathrm{O}_{2}(\mu \text { moles })\end{array}$ & $\begin{array}{l}\text { Dichromate/acetic acid } \\
\text { reagent }(\mathrm{ml})\end{array}$ & \multirow{7}{*}{$\begin{array}{l}\text { Formation of blue } \\
\text { precipitate and heat for } \\
10 \text { mins in boiling } \\
\text { water bath }\end{array}$} & \multirow{7}{*}{$\begin{array}{l}\text { Cool to room } \\
\text { temp and volume } \\
\text { is make upto } 3 \mathrm{ml} \\
\text { with DW }\end{array}$} & OD at $570 \mathrm{~nm}$ \\
\hline Blank & 0.0 & 0 & 2 & & & 0.0 \\
\hline $\mathrm{T} 1$ & 0.2 & 1 & 2 & & & 0.26 \\
\hline $\mathrm{T} 2$ & 0.4 & 2 & 2 & & & 0.33 \\
\hline $\mathrm{T} 3$ & 0.6 & 3 & 2 & & & 0.49 \\
\hline $\mathrm{T} 4$ & 0.8 & 4 & 2 & & & 0.65 \\
\hline T5 & 1.0 & 5 & 2 & & & 0.69 \\
\hline
\end{tabular}

Catalase Enzyme Assay

On $2^{\text {nd }}$ day(Table 13)

Table 13. Showing catalse enzyme assay on $2^{\text {nd }}$ day for measuring activity of catalse enzyme in bean seeds at normal temperature, $3^{\circ} \mathrm{C}$ and $-19^{\circ} \mathrm{C}$.

\begin{tabular}{|c|c|c|c|c|c|c|c|c|}
\hline SI.no & $\begin{array}{l}\text { Enzyme } \\
\text { extract(ml) }\end{array}$ & $\begin{array}{l}\text { Reaction } \\
\text { mixture(ml) }\end{array}$ & $\begin{array}{l}\text { Dichromate/ } \\
\text { acetic acid } \\
\text { reagent(ml) }\end{array}$ & \multirow{3}{*}{$\begin{array}{l}\text { Repeat this at } \\
60 \mathrm{sec} \\
\text { interval }\end{array}$} & \multirow{3}{*}{$\begin{array}{l}\text { Heat test } \\
\text { tubes for } 10 \\
\text { minsina a } \\
\text { boiling water } \\
\text { bath to get } \\
\text { green colour }\end{array}$} & \multirow[t]{2}{*}{$\begin{array}{l}\begin{array}{l}\text { OD at } 570 \\
\text { nm of } \\
\text { normal room } \\
\text { temp }\end{array} \\
0.37\end{array}$} & \multirow{2}{*}{$\begin{array}{l}\begin{array}{l}\text { OD at } 570 \\
\text { nm of } 3^{\circ} \mathbf{C}\end{array} \\
0.44\end{array}$} & \multirow{2}{*}{$\begin{array}{l}\begin{array}{l}\text { OD at } 570 \\
\text { nm of }-19^{\circ} \mathrm{C}\end{array} \\
0.46\end{array}$} \\
\hline Test & 1 & 1 & 2 & & & & & \\
\hline Blank & - & 1 & 2 & & & 0.0 & 0.0 & 0.0 \\
\hline
\end{tabular}

On $5^{\text {th }}$ day(Table 14)

Table 14. showing catalse enzyme assay on $5^{\text {th }}$ day for measuring activity of catalse enzyme in bean seeds at normal temperature, $3^{\circ} \mathrm{C}$ and $-19^{\circ} \mathrm{C}$.

\begin{tabular}{|c|c|c|c|c|c|c|c|c|}
\hline Sl.no & $\begin{array}{l}\text { Enzyme } \\
\text { extract(ml) }\end{array}$ & $\begin{array}{l}\text { Reaction } \\
\text { mixture(ml) }\end{array}$ & $\begin{array}{l}\text { Dichromate/acetic } \\
\text { acid reagent(ml) }\end{array}$ & \multirow{3}{*}{$\begin{array}{l}\text { Repeat } \\
\text { this at } \\
60 \mathrm{sec} \\
\text { interval }\end{array}$} & \multirow{3}{*}{$\begin{array}{l}\text { Heat test tubes } \\
\text { for } 10 \text { minsina a } \\
\text { boiling water } \\
\text { bath to get } \\
\text { green colour }\end{array}$} & $\begin{array}{l}\text { OD at } 570 \\
\text { nm of } \\
\text { normal room } \\
\text { temp }\end{array}$ & $\begin{array}{l}\text { OD at } 570 \\
\text { nm of } 3^{\circ} \mathrm{Cnh}\end{array}$ & $\begin{array}{l}\text { OD at } 570 \\
\mathrm{~nm} \text { of }-19^{\circ} \mathrm{C}\end{array}$ \\
\hline test & 1 & 1 & 2 & & & 0.18 & 0.20 & 0.22 \\
\hline Blank & - & 1 & 2 & & & 0.0 & 0.0 & 0.0 \\
\hline
\end{tabular}

\subsubsection{Result}

\section{Calculation}

$0.37 \mathrm{OD}$ at normal room temperature on $2^{\text {nd }}$ day corresponds to the decomposition of $90.265 \mu$ moles of $\mathrm{H}_{2} \mathrm{O}_{2}$ in a $3.0 \mathrm{ml}$ reaction mixture

Dilution factor $=10 \mathrm{x}$

Volume of sample $=1 \mathrm{ml}$

Interval of time $=1 \mathrm{~min}$

Activity of enzyme $(\mu \mathrm{moles} / \mathrm{min} / \mathrm{ml})=\mu$ moles of $\mathrm{H}_{2} \mathrm{O}_{2}$ *dilution factor/volume of enzyme*time = $90.265 * 10 / 1 * 1=902.65 \mu \mathrm{moles} / \mathrm{min} / \mathrm{ml}$

$0.44 \mathrm{OD}$ at $3^{\circ} \mathrm{C}$ on $2^{\text {nd }}$ day corresponds to the decomposition of $108.256 \mu$ moles of $\mathrm{H}_{2} \mathrm{O}_{2}$ in a $3.0 \mathrm{ml}$ reaction mixture

Dilution factor $=10 \mathrm{x}$

Volume of sample $=1 \mathrm{ml}$

Interval of time $=1 \mathrm{~min}$

Activity of enzyme $(\mu \mathrm{moles} / \mathrm{min} / \mathrm{ml})=\mu$ moles of
$\mathrm{H}_{2} \mathrm{O}_{2} *$ dilution factor/volume of enzyme*time = $108.256 * 10 / 1 * 1=1082.56 \mu$ moles $/ \mathrm{min} / \mathrm{ml}$

$0.46 \mathrm{OD}$ at $-19^{\circ} \mathrm{C}$ on $2^{\text {nd }}$ day corresponds to the decomposition of $116.252 \mu$ moles of $\mathrm{H}_{2} \mathrm{O}_{2}$ in a $3.0 \mathrm{ml}$ reaction mixture

Dilution factor $=10 \mathrm{x}$

Volume of sample $=1 \mathrm{ml}$

Interval of time $=1 \mathrm{~min}$

Activity of enzyme $(\mu \mathrm{moles} / \mathrm{min} / \mathrm{ml})=\mu$ moles of $\mathrm{H}_{2} \mathrm{O}_{2}$ *dilution factor/volume of enzyme*time = $116.252 * 10 / 1 * 1=1162.52 \mu \mathrm{moles} / \mathrm{min} / \mathrm{ml}$

$0.18 \mathrm{OD}$ at normal room temperature on $5^{\text {th }}$ day corresponds to the decomposition of $43.978 \mu$ moles of $\mathrm{H}_{2} \mathrm{O}_{2}$ in a $3.0 \mathrm{ml}$ reaction mixture

Dilution factor $=10 \mathrm{x}$

Volume of sample $=1 \mathrm{ml}$

Interval of time $=1 \mathrm{~min}$

Activity of enzyme $(\mu \mathrm{moles} / \mathrm{min} / \mathrm{ml})=\mu$ moles of $\mathrm{H}_{2} \mathrm{O}_{2}$ *dilution factor/volume of enzyme*time = 
$43.978 * 10 / 1 * 1=439.78 \mu \mathrm{moles} / \mathrm{min} / \mathrm{ml}$

$0.20 \mathrm{OD}$ at $3^{\circ} \mathrm{C}$ on $5^{\text {th }}$ day corresponds to the decomposition of $49.975 \mu$ moles of $\mathrm{H}_{2} \mathrm{O}_{2}$ in a $3.0 \mathrm{ml}$ reaction mixture

Dilution factor $=10 \mathrm{x}$

Volume of sample $=1 \mathrm{ml}$

Interval of time $=1 \mathrm{~min}$

Activity of enzyme $(\mu \mathrm{moles} / \mathrm{min} / \mathrm{ml})=\mu$ moles of $\mathrm{H}_{2} \mathrm{O}_{2}$ *dilution factor/volume of enzyme*time $=$ $49.975 * 10 / 1 * 1=499.75 \mu$ moles $/ \mathrm{min} / \mathrm{ml}$

$0.22 \mathrm{OD}$ at $-19^{\circ} \mathrm{C}$ on $5^{\text {th }}$ day corresponds to the decomposition of $53.973 \mu$ moles of $\mathrm{H}_{2} \mathrm{O}_{2}$ in a $3.0 \mathrm{ml}$ reaction mixture

Dilution factor $=10 \mathrm{x}$

Volume of sample $=1 \mathrm{ml}$

Interval of time $=1 \mathrm{~min}$

Activity of enzyme $(\mu \mathrm{moles} / \mathrm{min} / \mathrm{ml})$

$=\mu$ moles of $\mathrm{H} 2 \mathrm{O} 2$

* dilution factor/volume of enzyme

$*$ time $=53.973 * 10 / 1 * 1$

$=539.73 \mu$ moles $/ \mathrm{min} / \mathrm{ml}$

Table 15 Activity of catalase in bean seeds(Phaseolus vulgaris l)

Table 15. Showing Activity Of Catalase Enzymes In Bean Seeds At Normal Temperature, $3^{\circ} \mathrm{C}$ and $-19^{\circ} \mathrm{C}$.

\begin{tabular}{llll}
\hline Days & $\begin{array}{l}\text { Activity at normal } \\
\text { room temperature } \\
(\boldsymbol{\mu} \mathrm{moles} / \mathbf{m l} / \mathbf{m i n})\end{array}$ & $\begin{array}{l}\text { Activity at } \mathbf{3}^{\circ} \mathbf{C} \\
(\boldsymbol{\mu} \mathrm{moles} / \mathbf{m l} / \mathbf{m i n})\end{array}$ & $\begin{array}{l}\text { Activity at }-\mathbf{1 9}{ }^{\circ} \mathbf{C} \\
(\boldsymbol{\mu m o l e s} / \mathbf{m l} / \mathbf{m i n})\end{array}$ \\
\hline $2^{\text {nd }}$ day & 902.65 & 1082.56 & 1162.52 \\
$5^{\text {th }}$ day & 439.78 & 499.75 & 539.73 \\
\hline
\end{tabular}

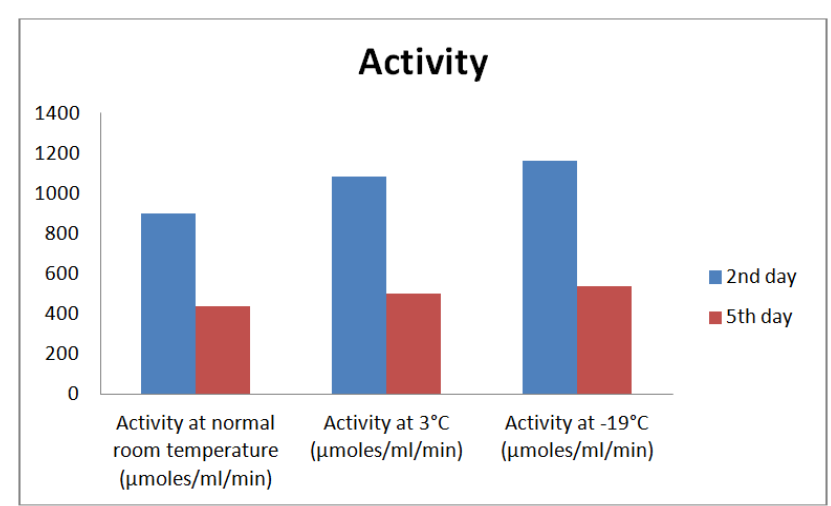

Graph 9. Showing activity of catalase enzymes in bean seeds at normal temperature, $3^{\circ} \mathrm{C}$ and $-19^{\circ} \mathrm{C}$.

\section{Discussion}

The $\mathrm{H}_{2} \mathrm{O}_{2}$ content showed highly significant differences between the control and tolerance to low temperatures. The normal room temperature had the lowest level of CAT activity and the highest $\mathrm{H}_{2} \mathrm{O}_{2}$ content. The lowest level of $\mathrm{H}_{2} \mathrm{O}_{2}$ was observed at the $3^{\circ} \mathrm{C}$ and $-19^{\circ} \mathrm{C}$ which shows the highest level of CAT activity. The results of our experiments demonstrate that low temperatures induce an accumulation of AOS (active oxygen species). AOS play a role in the photosystem II (PSII) operation (Willekens et al., 1997). The $\mathrm{H}_{2} \mathrm{O}_{2}$ accumulation was observed in the normal room temperature characterized by its sensitivity to cold (Vidalie, 1978). For the selected cold temperature, the low level of $\mathrm{H}_{2} \mathrm{O}_{2}$ is explained by the important CAT activity that at these temperature exhibit CAT are the first enzymes which take place in $\mathrm{H}_{2} \mathrm{O}_{2}$ neutralization and thus could avoid cellular damage caused by excessive accumulation of the substrate (Willekens et al., 1994). The importance of these enzymes under stress conditions are explored by several scientists (Foyer and Noctor, 2005). Puntarol et al. (1988) showed that the catalases are responsible for $\mathrm{H}_{2} \mathrm{O}_{2}$ elimination and that an over activity exhibition of these enzymes is able to induce hydrogen peroxide detoxification and is considered as a strategy for improving tolerance to the stress for plant cells. This is also proved by studies onrelationship between peroxidase and catalase with metabolism and environmentalfactors in (FagusorientalisLipsky) in three different elevations done by Zolfaghari,R , Hosseini,S.M , Korori ,S.A.A, in 2010.The activity of catalase in high elevation was significantly more than lower elevations in all collecting months except June and November. The increase of catalase activity in high elevation is due to lower temperature degree in winter and higher amount of light intensity and Ozone concentration. The results of this research show the lowest amount of catalase activity was in June. There was not any significant difference in catalase activity in three elevation classes. Also the catalase activity in high elevation was lower than other elevations in November in this month. The catalase activity started decreasing in February and reaches lowest amount in June and then started increasing until November.

\section{Summary and Conclusion}

Effect of cold stress was analyzed on bean seed phaseolus vulgaris $l$ by doing different types of tests (germination studies, respiration response, conductivity test, and amylase and catalase test) at different temperatures like at normal room temperature, at $3^{\circ} \mathrm{C}$ and at $-19^{\circ} \mathrm{C}$.

\section{Germination Study}

Effect of cold stress was analyzed on germination of bean seeds at different physiological parameters like germination percentage, germination rate, and seedvigour and germination index. Germination set up was made and seeds were kept for germination on moistened paper towel in a well-ventilated germination box and expose to different temperatures (normal room temperature, $3^{\circ} \mathrm{C}$ and $-19^{\circ} \mathrm{C}$ ). These experimental set up were observed for 15 days and their growth was recorded. It was observed that due to more chilling condition provided to the seed at $-19^{\circ} \mathrm{C}$, due to oxidative stress they were not able to grow so there were no germination percentage, germination rate, seed vigour and germination index. At $3^{\circ} \mathrm{C}$ there was growth but lesser than normal room temperature so germination percentage, germination rate, seed vigour and germination index all were lesser than normal room temperature. 


\section{Respiration Study}

Effect of cold stress was analyzed on respiration response of bean seeds. Experimental set up was made by placing three test tubes in the water containing beaker at different temperatures (normal room temperature, $3^{\circ} \mathrm{C}$ and $-19^{\circ} \mathrm{C}$ ). Those test tubes were filled with calcium hydroxide, cotton plug, seeds then again cotton plug and tied together with the rubber band. One set up was also kept for control without seeds to check respiration response till one week. It was observed that at $-19^{\circ} \mathrm{C}$ it starts respiring but due to ice formation it stopped. At $3^{\circ} \mathrm{C}$ it was respiring but little faster than normal room temperature. This stimulation of respiration was reported as adaptive behavior of seeds grown at cold conditions compared with related species from warmer conditions. The increased rate of respiration at low temperatures involves two energy dissipating systems, Alternative Oxidase (AOX) pathway and Plant Uncoupling Mitochondrial Protein (PUMP).

\section{Conductivity}

Effect of cold stress was analyzed on conductivity of seed leachate solution. These seed leachate were exposed to different temperatures (normal room temperature, $3^{\circ} \mathrm{C}$ and $19^{\circ} \mathrm{C}$ ). Conductivity was recorded by using conductivity meter followed by calibration of the instrument with potassium chloride. Conductivity measurement was done two days - on $1^{\text {st }}$ day and on $6^{\text {th }}$ day of germination. It was observed that leachate solution of $-19^{\circ} \mathrm{C}$ gives low conductivity whereas $3^{\circ} \mathrm{C}$ gives moderate and at normal room temperature it was high. Thus it was concluded that the electrical conductivity is based on the principle that the deterioration process is the leaching of the cells of seeds soaked in water due to loss of integrity of cellular systems. Thus, low conductivity means a high-quality seed.

\section{Amylase}

Amylase activity was studied at different temperature exposure(normal room temperature , $3^{\circ} \mathrm{C}$ and $-19^{\circ} \mathrm{C}$ ) to analyse cold stress. Standard maltose curve was done and plotted. Enzyme assay ofseeds exposed to different temperatures was carried out and maltose curve was calculated at different temperatures. Amylase enzyme assay was done two days- $2^{\text {nd }}$ day and $6^{\text {th }}$ day of germination. It was observed that amylase activity was greater at $-19^{\circ} \mathrm{C}$. Low temperature showed high amylase activity as there was high accumulation of starch in the seeds stored at low temperature and amylase activity will be high as it will be highly involved in the degradation of starch in to maltose. The greater the amount of maltose released the greater activity of amylase it will show.

\section{Catalase}

Catalase activity was studied at different temperature exposure (normal room temperature, $3^{\circ} \mathrm{C}$ and $-19^{\circ} \mathrm{C}$ ) toanalyze cold stress. Standard $\mathrm{H}_{2} \mathrm{O}_{2}$ curve was done and plotted. Enzyme assay ofseeds exposed to different temperatures was carried out and $\mathrm{H}_{2} \mathrm{O}_{2}$ curve activity was calculated at different temperatures. Catalase enzyme assay was done two days- $2^{\text {nd }}$ day and $5^{\text {th }}$ day of germination. It was observed that amylase activity was greater at $-19^{\circ} \mathrm{C}$. Seeds exposed to normal room temperature had the lowest level of CAT activity and the highest $\mathrm{H}_{2} \mathrm{O}_{2}$ content. The lowest level of $\mathrm{H}_{2} \mathrm{O}_{2}$ was observed at the $3^{\circ} \mathrm{C}$ and $-19^{\circ} \mathrm{C}$ which shows the highest level of CAT activity. The results of our experiments suggests that low temperatures induce an accumulation of AOS (active oxygen species).

\section{References}

[1] Abdul- Baki, A. and Anderson.J.D. 1973. Vigor determination in Soybean seed by multiple criteria. Crop Sci. 13, 630-633.

[2] Afiukwa, C. A., Ibiam, U. A., Edeogu, C. O., Nweke, F. N. and Chukwu, U. E. 2009. Determination of amylase activity of crude extract from partially germinated mango seeds (Mangiferaoraphila) African Journal of Biotechnology Vol. 8 (14), 3294-3296.

[3] AmjadHameed ,ShaziaNaseer; etal. 2008. Effects of $\mathrm{NaCl}$ salinity of seedling growth,senescence,catalase and protease activities in two wheat genotypes differing in salt tolerance, 19.

[4] Andreata, R.H.P. \& Pereira, T.S. 1990. Morfologia das plântulas de algumasespécies de Smilax L. Pesqui. Bot. 41, 724.

[5] AOSA-Association of Official Seed Analysts. 1983. Seed vigor testing handbook. Contribution No. 32 to the Handbook on Seed Testing. Association of Official Seed Analysts 93.

[6] Arun Dev Sharma, Meenu Thakur, MeenakshiRana and Kuldeep Singh.2004. Effect of plant growth hormones and abiotic stresses on germination, growth and phosphatase activities in Sorghum bicolor (L.) Moench seeds. African Journal of Biotechnology Vol. 3 (6), 308-312.

[7] Bewley, J.D., and Black, M. 1985. Seeds: Physiology of Development and Germination.Plenum Press, New York.

[8] Bing Bai, NogaSikron, Tanya Gendler, Yana Kazachkova, Simon Barak, Gideon Grafi,InnaKhozin-Goldberg and Aaron Fait.2011. Ecotypic Variability in the Metabolic Response of Seeds to Diurnal Hydration-Dehydration Cycles and its Relationship to Seed Vigor .Plant Cell Physiol. 53(1), 38-52.

[9] Bonner.F.T., 1991. Leachate Conductivity: A Rapid Nondestructive Test for Pine Seed Quality. Spring 41.

[10] Copeland, O.L. and M.B. Mcdonald, 1995. Seed science and technology. Third Edn, Chapman and Hall. New York.

[11] Davidson K.G.V. and Moore F.D., 1994.Comparison of Seedquality IndicesResulting from Single-seed Electroconductivity Measurements.Hortscience 29(10),1158-1163.

[12] Deisseroth.A and Dounce.A.L., 1970.Catalase: Physical and chemical properties, mechanism of catalysis, and physiological role. Physiol Rev. 50 (3), 319-75. 
[13] Delouche, J.C.; Baskin, C.C. 1973.Accelerated aging techniques for predicting the relative storability of seeds lots. Seed Science and Technology, Zurich. vol.1(2), p.427-452.

[14] Fatma Kaplan and Charles L. Guy, 2004. Beta-Amylase Induction and the Protective Role of Maltose during Temperature Shock, 135(3),1674-1684.

[15] Foolad M.R. and G.Y. Lin. 2000. Relationship between Cold Tolerance during Seed Germination and Vegetative Growth in Tomato: Germplasm Evaluation. J. Amer. Soc. Hort.Sci. 125(6),679-683.

[16] Foyer, C.H., Noctor, G., 2005. Redox homeostasis and antioxidant signalling: a metabolic interface between stress perception and physiological responses. Plant Cell 17, 18661875.

[17] Gupta P.C. Seed VigourTesting, 1984. 242-249.

[18] Gulzar S SangheraWani SH, Hussain W, Singh NB.2011. Engineering Cold Stress Tolerance in Crop Plants .Curr Genomics; 12(1),30-43.

[19] Hai-Yan Li,Chun-Guang Li.2011.Short-term cold-shock at 1 induced chilling tolerance in maize seedlings. 2010 International Conference on Biology, Environment and Chemistry.IPCBEEvol.1, IACSIT Press, Singapore.

[20] Hampton, J.G.; Johnstone, K.A.; Eua-umpon, V. 1992.Bulk conductivity test variables for Mungbean, Soybean and French bean seed lots. Seed Science and Technology, v.20,677-686.

[21] Hong-Xing Cao, Cheng-Xu Sun, Hong-Bo Shao,and Xin-Tao Lei.2011.Effects of low temperature and drought on the physiological and growth changes in oil palm seedlings. African Journal of Biotechnology Vol. 10(14), 2630-2637.

[22] Kaymakanova.M. 2000. Effect of Salinity on Germination and Seed Physiology in Bean (phaseolus vulgaris l.)Biotechnol. \&Biotechnol. Eq. 23/2009/se.

[23] Kenji Miura, and Tsuyoshi Furumoto, 2013. Cold Signaling and Cold Response in Plants.Int. J. Mol. Sci , 14, 5312-5337.

[24] Kennya Mara Oliveira Ramos, Juliana M.M. Matos, Rosana C. C.Martins, and IldeuS.Martins. 2012.Electrical Conductivity Testing as Applied to the Assessment of Freshly Collected Kielmeyeracoriacea Mart. Seed Technology Laboratory of Forestry .Seeds.5.

[25] Loeffler, T.M.; Tekrony, D.M.; Egli, D.B.1988. The bulk conductivity test as an indicator of soybean seed quality. Journal of Seed Technology, v.12, p.37-53.

[26] Lynn Vaccaro, 2003, Seed repirationteacher,CSIP publication.

[27] Makkawi, M., El Balla, M., Bishaw, Z. and Van Gastel, A. J. G.1999. The relationship between seed vigour tests and field emergence in lentil (Lens culinarisMedikus), Seed Sci. \&Technol., 27, 657-668.

[28] Maryam Madadkar., 2007.Photosynthesis and Respiration under Low Temperature Stress in Two DunaliellaStrainsmore. World Applied Sciences Journal 2 (4), 276-282.

[29] Matthews, S. and W.T. Bradnock. 1968. Relationship between seed exudation and field emergence in peas and French beans. Hort. Res.8, 89-93.
[30] Md. ShahidulHaque and Md. Kamal Hossain., 2011. A Regulatory Approach Caused by Cold Acclimation and Arsenic on the Impairment of Root Growth of Rice (Oryza sativa) .Jordan Journal of Biological Sciences. 4(4), 265- 274.

[31] Michael F. Thomashow.1998. Role of cold-responsive genes in plant freezing tolerance. Plant Physiol.118, 1-7.

[32] Michael F.Thomashow.2001. So What's New in the Field of Plant Cold Acclimation? Lots! Plant Physiology, vol. 125, 8993.

[33] Nabamita Chatterjee and Shantha Nagarajan.2006. Evaluation of water binding, Seed coat, permeability and germination characteristics of wheat seeds equilibrated at different relative humidities,Indian Journal of Biochemistry \&Biophysics,vol. 43, 233-238.

[34] Peter Bernfield .1955. In: Methods of Enzymology (EdsColowick, S and Kaplan, N O) Academic Press New York 1,149 .

[35] Phillips, R.; Rix, M. 1993. Vegetables. New York: Random House.

[36] Pieper, A. Das Saatgut. V.P. Darey Berlin.1952.Hamburg.

[37] Puntarol, S., Sanchez, R.A., Boveris, A., 1988. Hydrogen peroxide metabolism in soybean embryonic axes at the onset of germination. Plant Physiol. 86, 626-630.

[38] Roberts M.V.B., King .T.J.,1987. Biology.a functional approach student manual, $2^{\text {nd }}$ Edition, Thorns Nelson and Sons Ltd, 64-65.

[39] Sarka K., Kopecký .1990. Physics for Students of Pharmacy II. Bratislava.1-5.

[40] Sawney.S.K and Randhir Singh.1996.Determination of betaamylase activity in germinating bean seeds. Second edition. NarosaPublisihg House Pvt.Ltd. 148-149.

[41] Shashi Sharma, Rajender Kumar Sharma.2010.Long-term storage-dependent changes in seed physiological aspects of Hyoscyamusniger from a cold desert region of TransHimalaya.International Journal of Plant Biology, Vol.1(2), 13.

[42] Sinha AK,1972.Colorimetric assay of catalase. Anal Biochem. 47(2),389-94.

[43] SomenNandi,Gitali Das and Swati Sen.1994. $\beta$-amylase Activity as an Index for Germination potential in Rice. Annals of Botany 75,463-467.

[44] Su Jung Park, Kyung Jin Kwak, Tae Rin Oh, Yeon Ok Kim and Hunseung Kang.2009. Cold Shock Domain Proteins Affect Seed Germination and Growth of Arabidopsis thaliana under abiotic stress conditions. Plant Cell Physiol. 50(4), 869878.

[45] Suzuki N, Mittler R.2006. Reactive oxygen species and temperature stresses: A delicate balance between signaling and destruction. Physiol. Plant. 126, 45-51.

[46] Takahiro Tezuka, Hisa Yokoyama, Hideyuki Tanaka, ShujiShiozaki, and Masayuki Oda., 2012. Seed and Embryo Germination in Ardisiacrenata. Hindawi Publishing Corporation.Journal of Botany doi:10.1155/2012/679765.

[47] Tom Hamborg Nielsen, UtaDeiting. M Stitt; 1997. A PAmylase in Potato Tubers is induced by storage at low temperature. Plant Physiology, Vol. 113,503-510. 
[48] TuomasSopanen and Christiane Lauriere.1989. Release and activity of bound, b-amylase in a germinating barley grain. Plant Physiology,89, 244-249.

[49] Vladimir Shulaev and David J. Oliver. 2006. Metabolic and Proteomic Markers for Oxidative Stress. New Tools for Reactive Oxygen Species Research. Plant Physiol. vol. $141,367-370$.

[50] Vidalie, H., 1978. Comportement de diffe'rents cultivars de gla1"eulspre'cocescultive's sous tunnel. Pe'p. Hort. Mar. 192, $13-18$.

[51] Vieira, R.D.; Penariol, A.L.; Perecin, D.; Panobianco, M. 2002.Condutividade elétrica e teor de águainicial das sementes de soja. PesquisaAgropecuáriaBrasileira, v.37, p.1333-1338.

[52] Willekens, H., Chamnongpol, S., Davey, M., Schraudner, M., Langebartels, C., Van Montagu, M., Inzé, D., and Van Camp, W. 1997. Catalase is a sink for $\mathrm{H}_{2} \mathrm{O}_{2}$ and is indispensable for stress defense in $\mathrm{C}_{3}$ plants. EMBO J. 16, 4806-4816.
[53] Willekens, H., Langebartels, C., Tire', C., Van montagu, M., Inze', D., Van Camp, W., 1994. Differential expression of catalase genes in Nicotianaplumbaginifolia. Proc. Natl. Acad. Sci. U.S.A. 91, 10450-10454.

[54] Ya.JingGuan,Jin Hu. etal. 2009. Seed priming with chitosan improves maize germination and seedling growth in relation to physiological changes under low temperature stress, J Zhejiang UnivSci B. 10(6): 427-433.

[55] ZaferOlmez, AskinGokturk and SuleymanGulcu, 2006. Effects of cold stratification on germination rate and percentage of caper (CapparisovataDesf.) seeds. Journal of Environmental Biology, 27(4), 667-670.

[56] Zolfaghari R., Hosseini S. M., Korori S. A. A.2010. Relationship between peroxidase and catalase with metabolism and environmental factors in Beech (FagusorientalisLipsky) in three different elevations. International Journal of Environmental Sciences, vol $1(2), 243-252$. 